\title{
Three-dimensional dynamics of nitrogen from banded enhanced efficiency fertilizers
}

\author{
Chelsea K. Janke (id) Philip Moody • Michael J. Bell
}

Received: 26 November 2019/Accepted: 21 September 2020/Published online: 1 October 2020

(C) The Author(s) 2020

\begin{abstract}
A range of enhanced efficiency fertilizers (EEFs) have been developed in response to widespread recognition of poor nitrogen $(\mathrm{N})$ use efficiency (NUE) in agriculture; however, their effective utilization is not properly understood when applied in subsurface bands. This study quantified soil chemical changes and the distribution of $\mathrm{N}$ species that arose from sub-surface banding of urea, a controlled release polymer-coated urea (PCU) and urea coated with either nitrification inhibitors (NIs) or a urease inhibitor (UI), over 71 days in a field trial. Banding NIs extended the duration of nitrification inhibition for up to 50 days longer than banded urea, although the duration of NI-conferred inhibition was dependant on the rate of NI-urea application. The UI preserved urea-
\end{abstract}

Electronic supplementary material The online version of this article (https://doi.org/10.1007/s10705-020-10095-5) contains supplementary material, which is available to authorized users.

C. K. Janke $(\bowtie) \cdot$ M. J. Bell

School of Agriculture and Food Sciences, University of Queensland, Brisbane, Australia

e-mail: c.stroppiana@uq.edu.au

P. Moody

Landscape Sciences, Department of Environment and

Science, Queensland Government, Brisbane, Australia

M. J. Bell

Centre for Plant Science, Queensland Alliance for Agriculture and Food Innovation, University of

Queensland, Brisbane, Australia
$\mathrm{N}$ at a concentration which was 16-fold higher $c f$. standard urea over 7 days, but no urea-N was detected after 21 days. This suggests that the NUE benefits of UIs are transient when applied in sub-surface bands. Slow release of urea-N from banded PCU resulted in lower concentrations of $\mathrm{N}$ in the soil solution. This reduced $\mathrm{N}$ dispersal by $c a .50 \mathrm{~mm} c f$. urea, resulting in a N-enriched zone which was considerably smaller. Relatively benign chemical conditions around PCU bands enabled rates of nitrification $\left(\mathrm{NH}_{4}-\mathrm{N}: \mathrm{NO}_{3}-\mathrm{N}\right.$ ratio of $46 \%$ ) which were similar to urea. Collectively, these results demonstrate the relative efficacy and risks of the different EEF technologies, when applied in fertilizer bands. This knowledge supports the effective utilization of band-applied EEFs for improved NUE in agricultural systems.

Keywords Nitrogen use efficiency · Banding · Fertilizer management - Nitrification inhibitor · Urease inhibitor $\cdot$ Polymer-coated urea

\section{Introduction}

Nitrogen $(\mathrm{N})$ is frequently one of the most limiting nutrients to agricultural production, so crop responses to fertilizer-N application are often recorded. However, inappropriate fertilizer use can lead to a leakage of $\mathrm{N}$ from agricultural systems through leaching, over- 
land flow and gaseous emission. This $\mathrm{N}$ loss may disrupt the nutrient balance and dynamics of natural ecosystems, adversely impacting inhabitants and diminishing the ability of the ecosystem to provide services (Galloway et al. 2003; Hatfield and Follett 2008). With a growing world population driving increasing demand for agricultural products, there is a very real need to address $\mathrm{N}$ use efficiency (NUE) in a manner that enables sustainable intensification of agriculture without detrimental impacts on the surrounding environment.

The emergence of enhanced efficiency fertilizers (EEFs) on the $\mathrm{N}$-fertilizer market indicates recognition by industry that new fertilizer technology may provide a key tool for improving NUE in agriculture. Enhanced efficiency fertilizers utilise technologies such as nitrification inhibitors (NIs), urease inhibitors (UI), and controlled release products [e.g., polymercoated urea (PCU)]. Detailed descriptions of the mode-of-action for these technologies can be found in McCarty (1999), Shaviv (2001) and Engel et al. (2015). Briefly, NIs inhibit the oxidisation of ammonia $\left(\mathrm{NH}_{3}\right)$ to nitrite $\left(\mathrm{NO}_{2}{ }^{-}\right)$; UIs function by restricting the conversion of urea to ammonium $\left(\mathrm{NH}_{4}{ }^{+}\right)$; and $\mathrm{PCU}$ slows the release of urea into the soil solution. These technologies aim to improve the synchrony of fertilizer-N availability with plant demand by minimizing the time when $\mathrm{N}$ is in a form, such as nitrate $\left(\mathrm{NO}_{3}-\mathrm{N}\right)$, which is susceptible to loss from agricultural systems.

However, while EEFs have been widely investigated (Alonso-Ayuso et al. 2016; Barker and Sawyer 2017; Engel et al. 2015; Rowlings et al. 2016), there has been little research into the interaction between EEFs and fertilizer application method. Specifically, much of the research into EEFs has employed broadcast and/or incorporated placement of N-fertilizer, with few studies utilizing banded fertilizer application. Those that do (Lester et al. 2016; Scheer et al. 2016; Wang et al. 2016) typically focus analysis on agronomic responses or gaseous $\mathrm{N}$ emissions. This is not a comprehensive assessment of EEF behaviour in soils and consequently, the extrapolation of effective EEF utilization to other environments and scenarios is limited. Banding fertilizers in or near the root zone is a method of enhancing the opportunity for nutrient uptake by plants and minimising the risk of nutrient losses (Sanchez et al. 1990; Sandral et al. 2017); it is also an increasingly common practice in crop production for minimising soil disturbance associated with tillage. However, banding N-fertilizers creates a vastly different biochemical environment in which $\mathrm{N}$ transformations will occur, compared to when the same product is broadcast or mixed into soil (Bezdicek et al. 1971; Hauck and Stephenson 1965; Janke et al. 2019; Passioura and Wetselaar 1972; Wetselaar et al. 1972). This alteration in soil biochemistry is likely to impact EEF efficacy and will have implications for the effective utilization of EEF products when applied in sub-surface fertilizer bands.

The main objective of the current study was therefore to assess the performance of a range of band-applied EEFs in the field, by measuring the vertical and lateral distribution and transformations of fertilizer-N. The performance of different urea-based EEF products were contrasted to that of a standard urea band to identify any NUE benefits that may be realised from the adoption of different EEF technologies (i.e., NIs, UIs, or polymer coating). In addition, several rates of a NI treatment were included to give a preliminary indication of the potential for rate manipulation and the effect of in-band $\mathrm{N}$ concentration on $\mathrm{NI}$ efficacy. The direct measurement of $\mathrm{N}$ transformations and the associated soil biochemistry complements the wide body of literature reporting symptomatic effects (viz., yield, growth indicators, $\mathrm{N}_{2} \mathrm{O}$ emissions, etc.) of EEFs in the field (Kawakami et al. 2012; Li et al. 2015; Nash et al. 2013; Thapa et al. 2016). The results provide a mechanistic understanding of how EEFs impact soil $\mathrm{N}$ transformations when applied in sub-surface bands.

\section{Materials and methods}

Site description

The field experiment was undertaken in a black Vertosol (Isbell 2016) at the University of Queensland research station $\left(27^{\circ} 34^{\prime} 06^{\prime \prime} \mathrm{S}, 152^{\circ} 19^{\prime} 55^{\prime \prime} \mathrm{E}\right)$, Gatton Campus, Queensland, Australia. The key soil characteristics are presented in Table 1. The site has been regularly used for forage production.

Preparation of field site

In mid-September 2017, the site was disced and then rotary hoed to prepare for a cover crop. Forage sorghum (Sorghum spp. var. Super Sweet Sudan) was 
Table 1 Chemical and physical characteristics of the field soil $(0.10 \mathrm{~m}$ depth $)$

\begin{tabular}{lllllllllllll}
\hline Order $^{\mathrm{a}}$ & Location & Colour & $\begin{array}{l}\text { Coarse } \\
\text { sand }\end{array}$ & $\begin{array}{l}\text { Fine } \\
\text { sand }\end{array}$ & Silt & Clay & pH (1:5 & $\begin{array}{l}\text { EC (1:5) } \\
\text { water }) \\
\left(\mathrm{dS} \mathrm{m}^{-1}\right)\end{array}$ & $\begin{array}{l}\text { eCEC } \\
\left(\mathrm{mmol}_{\mathrm{c}}\right. \\
\mathrm{kg}^{-1} \text { soil) }\end{array}$ & $\begin{array}{l}\text { Mineral N } \\
\left(\mathrm{mg} \mathrm{kg}^{-1}\right)\end{array}$ & $\begin{array}{l}\mathrm{NO}_{3}-\mathrm{N} \\
\left(\mathrm{mg}^{-1}\right. \\
\left.\mathrm{kg}^{-1}\right)\end{array}$ & $\begin{array}{l}\mathrm{TOC} \\
(\%)\end{array}$ \\
\hline Vertosol & Gatton & Grey & 3 & 16 & 21 & 62 & 7.8 & 0.07 & 493 & 2 & $<1$ \\
\hline
\end{tabular}

${ }^{\mathrm{a}}$ Isbell (2016)

Where PSA refers to particle size analysis; $\mathrm{pH}$ (1:5 soil:water); EC (1:5 soil:water), electrical conductivity; eCEC, effective cation exchange capacity; N, nitrogen; TOC, total organic carbon

drilled at a rate of $33 \mathrm{~kg} \mathrm{ha}^{-1}$ to a depth of $c a .0 .05 \mathrm{~m}$ in rows $0.50 \mathrm{~m}$ apart. The crop was cut and removed as hay $c a$. one month after planting to deplete background mineral $\mathrm{N}$ reserves. This was followed by an application of natural gypsum at a rate of $1 \mathrm{~T} \mathrm{ha}^{-1}$, which was broadcast onto the ratooning forage sorghum crop. In mid-January, the forage sorghum was cut and removed again, with plant growth indicating little residual $\mathrm{N}$ remaining in the soil. The field was then ripped to a depth of $c a .0 .30 \mathrm{~m}$, and subsequently rotary hoed. One day prior to the application of fertilizer treatments, the site was sprayed with S-Metolachlor $\left(1.92 \mathrm{~kg} \mathrm{ha}^{-1}\right)$ and Atrazine $\left(1.25 \mathrm{~kg} \mathrm{ha}^{-1}\right)$ to control weeds.

\section{Treatment application}

Fertilizer treatments were applied at in-band concentrations equivalent to those when 50 to $150 \mathrm{~kg} \mathrm{~N} \mathrm{ha}^{-1}$ are applied at band spacings of $1.8 \mathrm{~m}$ (viz. 9-27 $\mathrm{g} \mathrm{N}$ $\mathrm{m}^{-1}$ ), with the high in-band concentration typical of that used in the sugarcane and cotton industries (Bell et al. 2014; Rochester and Bange 2016). The treatments were placed in $10 \mathrm{~m}$ plot lengths with $0.75 \mathrm{~m}$ between individual bands and a buffer of $2.5 \mathrm{~m}$ separating treatments. Four replications of each treatment were arranged in a randomized complete block design. Fine white sand was mixed with the N-fertilizer to allow for subsequent identification of the band location in the soil profile.

Treatments were: (i) Control (no $\mathrm{N}$ applied); (ii) urea low ( $9 \mathrm{~g} \mathrm{~N} \mathrm{~m}^{-1}$ of row); (iii) urea medium (18 $\mathrm{g}$ $\mathrm{N} \mathrm{m}^{-1}$ of row); (iv) urea high (27 $\mathrm{g} \mathrm{N} \mathrm{m}^{-1}$ of row); (v) ENTEC $\AA$ low $\left(9 \mathrm{~g} \mathrm{~N} \mathrm{~m}^{-1}\right.$ of row); (vi) ENTEC $\AA$ medium (18 $\mathrm{g} \mathrm{N} \mathrm{m}^{-1}$ of row); (vii) ENTEC ${ }^{\circledR}$ high (27 $\mathrm{g} \mathrm{N} \mathrm{m}^{-1}$ of row); (viii) 3,4 dimethylpyrazol succinic acid (DMPSA)-urea high $\left(27 \mathrm{~g} \mathrm{~N} \mathrm{~m}^{-1}\right.$ of row); (ix) Green Urea NV® high $\left(27 \mathrm{~g} \mathrm{~N} \mathrm{~m}^{-1}\right.$ of row); and (x) Agromaster Tropical ${ }^{\circledR}$ high (27 g N $\mathrm{m}^{-1}$ of row ). Urea was standard granular urea, which is commonly used as a $\mathrm{N}$ source in many agricultural industries. ENTEC ${ }^{\circledR}$ is granular urea coated with the nitrification inhibitor 3,4-dimethylpyrazole phosphate (DMPP) at a rate of $1.84 \mathrm{~g}^{\mathrm{DMPP}} \mathrm{kg}^{-1}$ urea. The DMPSA treatment is a urea product coated with a blend of DMPP and succinic acid, also aiming to deliver inhibitory properties to nitrification (Pacholski et al. 2016). Green Urea NV® is a granular urea coated with the urease inhibitor (N-(n-butyl) thiophosphoric triamide) (NBPT) at a rate of $0.48 \mathrm{~g} \mathrm{NBPT} \mathrm{kg}^{-1}$ urea. Agromaster Tropical ${ }^{\circledR}$ is a polymer coated urea with a reported 90-day release profile (Impact Fertilizers 2019). Hereafter, the treatments are referred to by their active ingredient/coating and/or base ingredient and rate as: (i) control; (ii) urea low; (iii) urea medium; (iv) urea high; (v) DMPP-urea low; (vi) DMPP-urea medium; (vii) DMPP-urea high; (viii) DMPSA-urea high; (ix) NBPT-urea high; and (x) PCU high.

Soil environment and rainfall/irrigation

Following $\mathrm{N}$-fertilizer application, electronic data loggers were set up at three points across the experimental site to record soil temperature $\left({ }^{\circ} \mathrm{C}\right)$ at $0.10 \mathrm{~m}$ using 5TM Sensor probes (Decagon, 5TM Soil Moisture and Temperature). A rainfall sensor (ECRN100) was set up in the middle of the site to record irrigation and rainfall events $(\mathrm{mm})$. ECH2O software was used to download and interpret data from the data loggers. Soil moisture data were collected at 30-min intervals using two frequency domain reflectance probes (Sentek EnviroSCAN) at depths of 0.10 and 
$0.30 \mathrm{~m}$ below the soil surface. Raw data were converted to volumetric water content using soil water characteristics defined by pressure plate methods.

\section{Soil sample collection}

During sampling events, a small trench was dug perpendicular to the fertilizer band. When white sand (identifying the $\mathrm{N}$ band) was located on the two opposing faces of the trench, a string line was aligned over the band on the soil surface, and extended a small distance from the trench. A $350 \times 200 \times 70 \mathrm{~mm}$ $(1 \times b \times d)$ metal open-face profile sampler, with a small notch at the bottom to allow for centre-of-band alignment with the string line, was inserted to a depth of $0.25 \mathrm{~m}$. A $350 \times 200 \mathrm{~mm}(1 \times \mathrm{b})$ piece of sheet metal was inserted vertically down the open front of the profile sampler to a depth of $c a .0 .25 \mathrm{~m}$. The sheet metal and profile sampler were clamped together and the entire unit was removed from the soil by excavation. The clamps were detached and a clay cutting wire was run between the sheet metal and profile sampler to remove the front face (sheet metal) without disturbing the soil profile. The intact soil blocks were wrapped in plastic packing wrap and transported to cold room storage $\left(3-5^{\circ} \mathrm{C}\right)$ prior to sectioning and sampling.

In the laboratory, the soil blocks for each treatment were sectioned using a $50 \mathrm{~mm}$ grid (measuring from the bottom left corner), with 9 individual zones collected for analysis at varying height, depth, and lateral distances from the band zone. The analysed zones included (distances as mm from centre of band zone): (1) 75-125 mm directly above; (2) $25-75 \mathrm{~mm}$ at $45^{\circ}$ above; (3) $25-75 \mathrm{~mm}$ directly above; (4) 75-125 mm lateral distance; (5) 25-75 mm lateral distance; (6) band zone (designated the 'fertosphere'): 0-25 mm horizontal and vertical; (7) $25-75 \mathrm{~mm}$ at $45^{\circ}$ below; (8) 25-75 mm directly below; and (9) $75-125 \mathrm{~mm}$ directly below (see Supplementary Fig. S2). At 49 and 71 days after fertilization (DAF), the sampling method varied slightly, with only three soil samples taken directly from the exposed soil profile using horizontally inserted $50 \mathrm{~mm}$ diameter sample tubes. These samples pertained to zones 3 (25-75 mm directly above band), 6 (centre of band to $25 \mathrm{~mm}$ horizontally and vertically), and 8 (25-75 $\mathrm{mm}$ directly below band). At all sampling times, soil within each individual zone was mixed to homogenize, and two representative samples of $10 \mathrm{~g}$ soil were taken. One sample (10 g) was used for analysis of $\mathrm{pH}_{1: 5 \mathrm{w}}$ and $\mathrm{EC}_{1: 5}$, the other sample (10 g) was used to determine $\mathrm{KCl}$-extractable $\mathrm{N}$. Where urea-N measurements were undertaken, a separate $2 \mathrm{~g}$ soil sample was taken and immediately frozen prior to extraction and analysis.

Soil $\mathrm{pH}_{1: 5 \mathrm{w}}$ and $\mathrm{EC}_{1: 5}$

The $\mathrm{pH}_{1: 5 \mathrm{w}}$ and $\mathrm{EC}_{1: 5}$ of soil samples were measured in a 1:5 $(w / v)$ soil-water solution by adding $50 \mathrm{~mL}$ deionized water to $10 \mathrm{~g}$ soil. Both $\mathrm{pH}_{1: 5 \mathrm{w}}$ and $\mathrm{EC}_{1: 5}$ were measured using a pH/EC Robot (Labfit AS-3020, Australia) with $60 \mathrm{~s}$ of stirring prior to measurement. The $\mathrm{pH}_{1: 5 \mathrm{w}}$ was recorded when multiple (5) values within a range of 0.02 units were recorded, and likewise $\mathrm{EC}_{1: 5}$ values were taken when variation between 5 readings was within $0.02 \mathrm{dS} \mathrm{m} \mathrm{m}^{-1}$. A maximum reading time length of $60 \mathrm{~s}$ was set for the $\mathrm{pH}_{1: 5 \mathrm{w}}$ and $\mathrm{EC}_{1: 5}$ of each sample. Values for $\mathrm{pH}_{1: 5 \mathrm{w}}$ were arithmetically averaged from four replicate samples, and this was checked against the geometrical mean of $\mathrm{H}^{+}$concentrations to ensure correct interpretation (Boutilier and Shelton 1980). Electrical conductivity values $\left(\mathrm{dS} \mathrm{m} \mathrm{m}^{-1}\right)$ were similarly averaged from four replicate samples.

\section{Soil N extraction}

Urea-N analysis was carried out by high performance liquid chromatography (HPLC) of 1:5 soil-water $(w / v)$ extracts, using a Thermo Fisher Ultimate $3000 \mathrm{U}$ HPLC system (Germany) with a Thermo Fisher DAD 3000 diode array detector and following modified versions of the methods detailed for urea (MicroSolv 2010). Data were processed using Chromeleon 7.4 acquisition software and results are reported as $\mathrm{mg}$ $\mathrm{L}^{-1}$. Urea-N values from HPLC analysis were expressed as the solution concentration (mg urea-N $\mathrm{L}^{-1}$ ) of extractions. Extraction of mineral $\mathrm{N}$ followed standard methods (Method 7C2a: Rayment and Lyons 2010), using a 1:5 (w/v) ratio with $2 \mathrm{M} \mathrm{KCl}$ (i.e., $10 \mathrm{~g}$ soil with $50 \mathrm{~mL} 2 \mathrm{M} \mathrm{KCl}$ ). Following centrifuging, extracts were analysed by segmented flow analysis for $\mathrm{NH}_{4}-\mathrm{N}$ (Searle 1974), and $\mathrm{NO}_{2}-\mathrm{N}$ and $\mathrm{NO}_{\mathrm{x}}-\mathrm{N}$ (Best 1976; Bremner 1965). Concentrations of $\mathrm{NO}_{3}-\mathrm{N}$ were determined by calculating the difference between $\mathrm{NO}_{\mathrm{x}}-\mathrm{N}$ and $\mathrm{NO}_{2}-\mathrm{N}$ (Best 1976; Bremner 1965). Mineral $\mathrm{N}$ values are reported as $\mathrm{mg} \mathrm{N} \mathrm{kg} \mathrm{soil}{ }^{-1}$ (1:5 
$w / v 2 \mathrm{M} \mathrm{KCl}$ ). Ammonia (aqueous $\mathrm{NH}_{3}$ ) concentrations were calculated by applying the $\mathrm{pK}_{\mathrm{a}}$ value of the $\mathrm{NH}_{4}{ }^{+} \leftrightarrow \mathrm{NH}_{3}$ reaction at $25^{\circ} \mathrm{C}$ (Emerson et al. 1975), then determining the $\mathrm{NH}_{3}$ (molarity) from known $\mathrm{K}_{\mathrm{a}}$, $\mathrm{H}^{+}$(molarity), and $\mathrm{NH}_{4}{ }^{+}$(molarity) values in soil solution, as per Eq. 1 (Erickson 1985). Quantities of ammonia were calculated by determining the moles in solution, multiplying by the molecular weight of $\mathrm{NH}_{3}$ and expressing as $\mathrm{mg} \mathrm{NH}_{3} \mathrm{~L}^{-1}$.

$\mathrm{NH}_{3}=\frac{\mathrm{K}_{a} \times N H_{4}^{+}}{\mathrm{H}^{+}}$

\section{Statistical analysis}

Statistical significance was determined by multiple ANOVAs to test the effects of (i) time; (ii) position (zones 6 and 8 only, as these were consistently measured over the 71-day experiment and were most impacted by the fertilizer band); (iii) $\mathrm{N}$-fertilizer treatment; and the interactions of each of these factors. Statistical output for $\mathrm{NH}_{4}-\mathrm{N}$ is presented in Supplementary Material (Tables S1, S2); output for other measurements (urea-N, $\mathrm{NO}_{3}-\mathrm{N}, \mathrm{NO}_{2}-\mathrm{N}$, aqueous $\mathrm{NH}_{3}, \mathrm{pH}$, and $\mathrm{EC}$ ), post-hoc analysis and mean $+\mathrm{s}-$ tandard error tables are available on request.

\section{Results and discussion}

Environmental conditions during the study

Changes in soil moisture and temperature over the duration of the trial period will have potentially large impacts on the rate of $\mathrm{N}$ transformations and the possible movement of fertilizer-N out of the monitoring zone (i.e., the top $0.25 \mathrm{~m}$ of the soil profile). The soil temperature at a depth of $0.10 \mathrm{~m}$ averaged $26{ }^{\circ} \mathrm{C} \pm 4{ }^{\circ} \mathrm{C}$, with the highest temperatures occurring in the first month after fertilizer application and slowly declining thereafter (Fig. 1). The trial site received $450 \mathrm{~mm}$ of rainfall and irrigation during the 71-day monitoring period (Fig. 1), which primarily fell in three discrete wet periods. The first $150 \mathrm{~mm}$ fell within the first $7 \mathrm{DAF}$, a further $190 \mathrm{~mm}$ fell over a 10-day period between 18 and $28 \mathrm{DAF}$ and $70 \mathrm{~mm}$ fell over a 3-day period from 53 to $55 \mathrm{DAF}$. The first two events in particular were large enough to cause short term waterlogging and trigger either leaching of $\mathrm{NO}_{3}-$
$\mathrm{N}$ into deeper profile layers or denitrification losses to the atmosphere [D. Rowlings (2019)-unpublished data]. In the absence of crop transpiration, the soil remained relatively moist for most of the incubation period despite the evaporative losses that occurred between rainfall events.

\section{Unfertilized soil reactions over time}

The distribution of $\mathrm{N}$ species (see Supplementary Material, Fig. S3) and the fluxes of $\mathrm{pH}_{1: 5 \mathrm{w}}$ and $\mathrm{EC}_{1: 5}$ (see Supplementary Material, Fig. S4) in the unfertilized soil profile (Control) are a result of variation in physico-chemical processes (i.e., solubilisation, precipitation, etc.), biological processes (decomposition, mineralization, etc.) (Carmo et al. 2016; Gerla 2013), and the effects of environmental conditions (i.e., wetdry cycles, moisture content, water movement through soil, temperature, etc.) over time. Changes in these processes were used to benchmark the impact of fertilizer application.

In general, $\mathrm{pH}_{1: 5 \mathrm{w}}$ increased slightly with depth, although $\mathrm{pH}_{1: 5 \mathrm{w}}$ tended to be lowest in the 0.10-0.15 m depth (ca. 7.38) over the first 21 DAF (Fig. S4). From 49 DAF, $\mathrm{pH}_{1: 5 \mathrm{w}}$ values throughout the measured profile demonstrated a substantial decline of ca. $0.34 \mathrm{pH}$ units and continued to exhibit acidification up to $71 \mathrm{DAF}$. This is consistent with increased nitrifying activity (Carmo et al. 2016) as indicated by increasing $\mathrm{NO}_{3}-\mathrm{N}$ and decreasing $\mathrm{NH}_{4}-\mathrm{N}$ concentrations at 49 and 71 DAF in untreated soil (Fig. S3). This also coincides with moderate increases in $\mathrm{EC}_{1: 5}$ ( $c a$. $0.10 \mathrm{dS} \mathrm{m}^{-1}$, Fig. S4) at 49 DAF whereby higher concentrations of soluble $\mathrm{NO}_{3}-\mathrm{N}$ likely contributed to the higher dissolved salt concentration. The initial flush of mineralization at 21 DAF (Fig. S3) was most pronounced in the disturbed soil in and around the position of the fertilizer tine (i.e., zones $1,3,6,8$ and 9-Fig. S2), and occurred in response to the increased soil moisture from irrigation and rainfall in the week following fertilizer application (Fig. 1). The relative proportions of mineral $\mathrm{N}$ present as $\mathrm{NH}_{4}-\mathrm{N}$ and $\mathrm{NO}_{3}-$ $\mathrm{N}$ fluctuated during the monitoring period (Fig. S3), with $\mathrm{NH}_{4}-\mathrm{N}$ concentrations tending to dominate the mineral $\mathrm{N}$ species for the first 30 days of the experiment. After that, $\mathrm{NO}_{3}-\mathrm{N}$ was the principal mineral $\mathrm{N}$ species present as nitrification became the dominant $\mathrm{N}$ transformation process. 

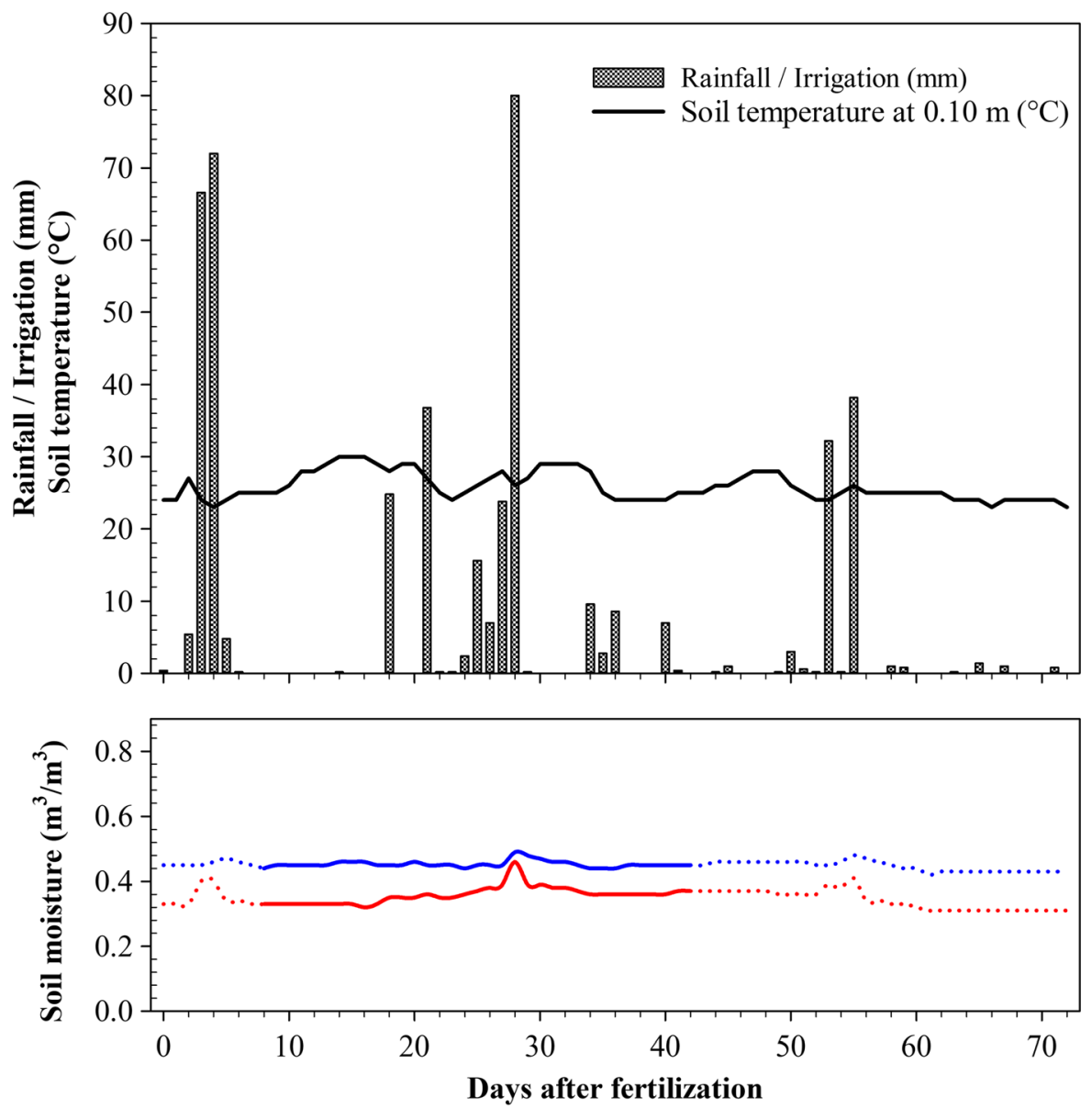

- Moisture at $0.10 \mathrm{~m} \longrightarrow$ Moisture at $0.30 \mathrm{~m}$

Fig. 1 Time scale of rainfall and irrigation $(\mathrm{mm})$, temperature fluxes $\left({ }^{\circ} \mathrm{C}, 0.10 \mathrm{~m} \mathrm{depth}\right)$ and the average soil moisture $\left(\mathrm{m}^{3}\right.$ water $\mathrm{m}^{3}$ soil $^{-1}$ ) at 0.10 and $0.30 \mathrm{~m}$ depths, where the dotted line indicates predicted values in the absence of direct measurement

While the absence of plants in this experiment prevented the determination of $\mathrm{N}$ dynamics in response to an actively growing crop, it facilitated the understanding of $\mathrm{N}$ fluxes in the soil without the confounding effects of crop water and $\mathrm{N}$ uptake. This enabled a comprehensive investigation of banded EEF behaviour and efficacy under field conditions that can be broadly applied to a range of agricultural systems.

Biochemical reactions and $\mathrm{N}$ dynamics of banded urea and EEFs

The impact of banded EEFs on biochemical reactions in the soil were investigated by comparing the 3-dimensional distribution and persistence of $\mathrm{N}$ species over time. From this, EEF effects on major processes [urea hydrolysis, the equilibria of $\mathrm{NH}_{4}{ }^{+}$and $\mathrm{NH}_{3}$, and nitrification (see Supplementary Material, Fig. S1)] were compared to a granular urea standard. Accordingly, the following discussion describes these processes in detail for standard urea and then focuses on the impact of each of the EEF technologies and implications for NUE. The influence of both the physico-chemical properties of the Vertosol and the mass flow of soil water on the efficacy of EEFs were also considered in this analysis (Nye 1979).

Banding standard urea induces inhibition of ureolytic activity and nitrification

Typically, the hydrolysis of applied urea in soils completes within 2-4 days (Antil et al. 2009; 
Christianson et al. 1993). However, some urea-N (viz. $45 \mathrm{mg} \mathrm{N} \mathrm{kg}^{-1}$ soil) was still present at 7 DAF in soil within the fertosphere and directly below the band (to
$75 \mathrm{~mm}$, Fig. 2). Rainfall from 2 to 5 DAF (Fig. 1) likely contributed to the vertical distribution of urea-N down the profile. This zone of incomplete urea

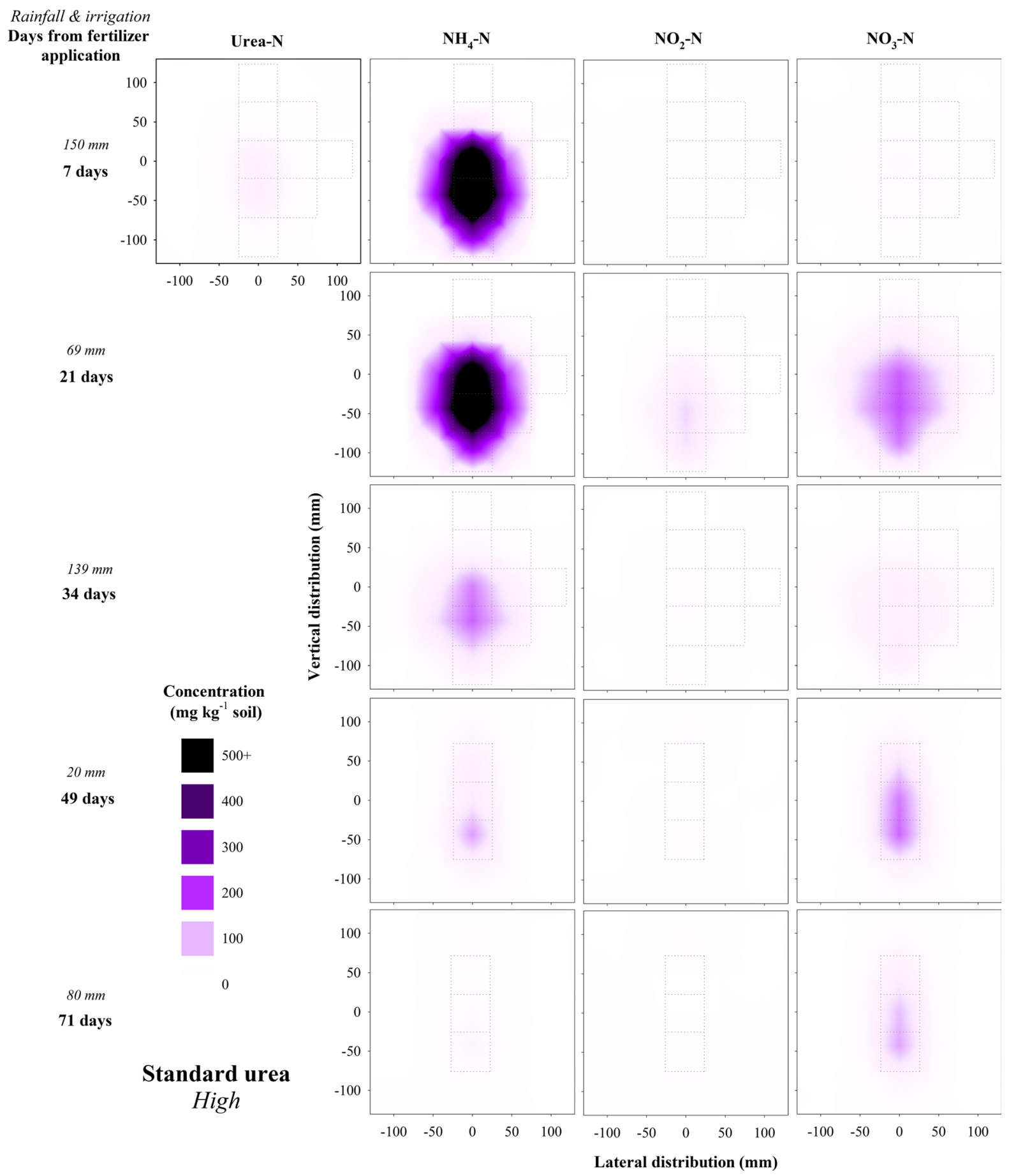

Fig. 2 Distribution of $\mathrm{N}$ species ( $\mathrm{mg} \mathrm{N} \mathrm{kg}^{-1}$ soil) over time in soil treated with the high in-band concentration $\left(27 \mathrm{~g} \mathrm{~N} \mathrm{~m}^{-1}\right)$ of banded urea. No measurement of urea-N was taken after 7 days. The grid indicates the zones (Fig. S2) that were sampled at each time point 
hydrolysis suggests there was moderate inhibition of urease activity over the first week following application, where the initially high urea-N concentrations may have been sufficient to induce substrate (urea-N) saturation of urease (Bhat et al. 2011; Singh and Nye 1984). Alternatively, the high $\mathrm{pH}_{1: 5 \mathrm{w}}$ (ca. 8.20-8.30, Fig. 3) in the fertosphere may have reduced the affinity of urease for urea-N molecules, which has been observed even at low urea-N concentrations (Singh and Nye 1984).

Regardless of the apparent inhibition of some ureolytic activity, $\mathrm{NH}_{4}-\mathrm{N}$ persisted at concentrations of $c a .700-830 \mathrm{mg} \mathrm{N} \mathrm{kg} \mathrm{soil}^{-1}$ in the same zones until at least 21 DAF (Fig. 2). Significantly elevated concentrations of $\mathrm{NH}_{4}-\mathrm{N}$ were also recorded at $125 \mathrm{~mm}$ below the band and at $75 \mathrm{~mm}$ laterally and diagonally below the band at that time. The detection of $\mathrm{NH}_{4}-\mathrm{N}$ at these depths, which are further from the fertosphere than was recorded for urea-N (Fig. 2), suggests there may have been some leaching of urea-N which was followed by rapid hydrolysis to $\mathrm{NH}_{4}-\mathrm{N}$ at these depths. Alternatively, the deeper distribution of $\mathrm{NH}_{4}-\mathrm{N}$ may have been due to leaching of aqueous $\mathrm{NH}_{3}$. Elevated concentrations of aqueous $\mathrm{NH}_{3}$ were observed within the fertosphere and below at 7 DAF (Fig. 4), as a consequence of the high $\mathrm{NH}_{4}-\mathrm{N}$ concentrations and elevated $\mathrm{pH}$ (Fig. 3) in those zones (Emerson et al. 1975; Erickson 1985). The $\mathrm{NH}_{4}-\mathrm{N}$ at

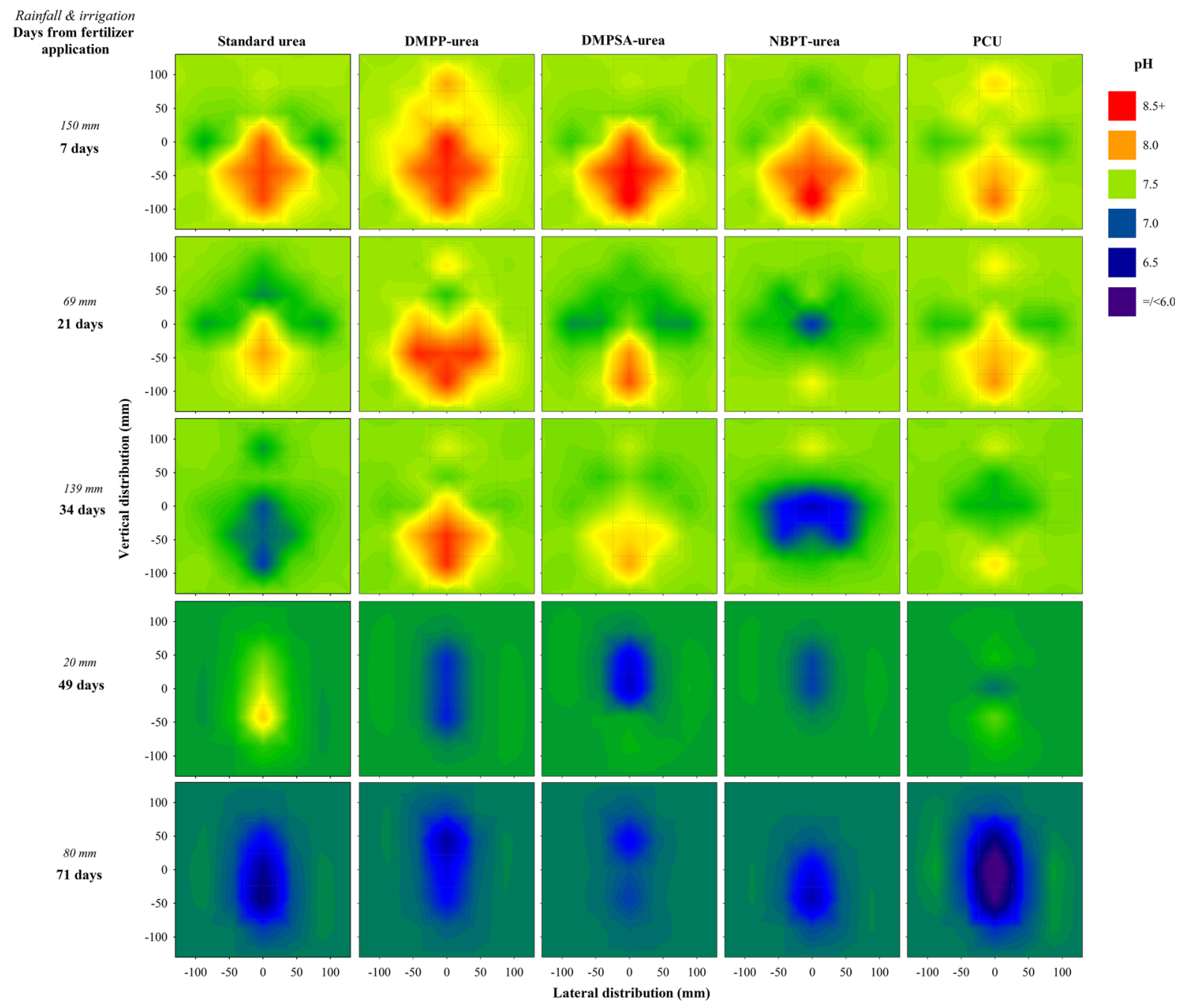

Fig. 3 Heat maps of $\mathrm{pH}$ fluxes over time in response to banded $\mathrm{N}$-fertilizer treatments. The $\mathrm{pH}$ indicated outside the sample zone (marked with grid) is representative of the average $\mathrm{pH}$ throughout the profile in control soil at that time 


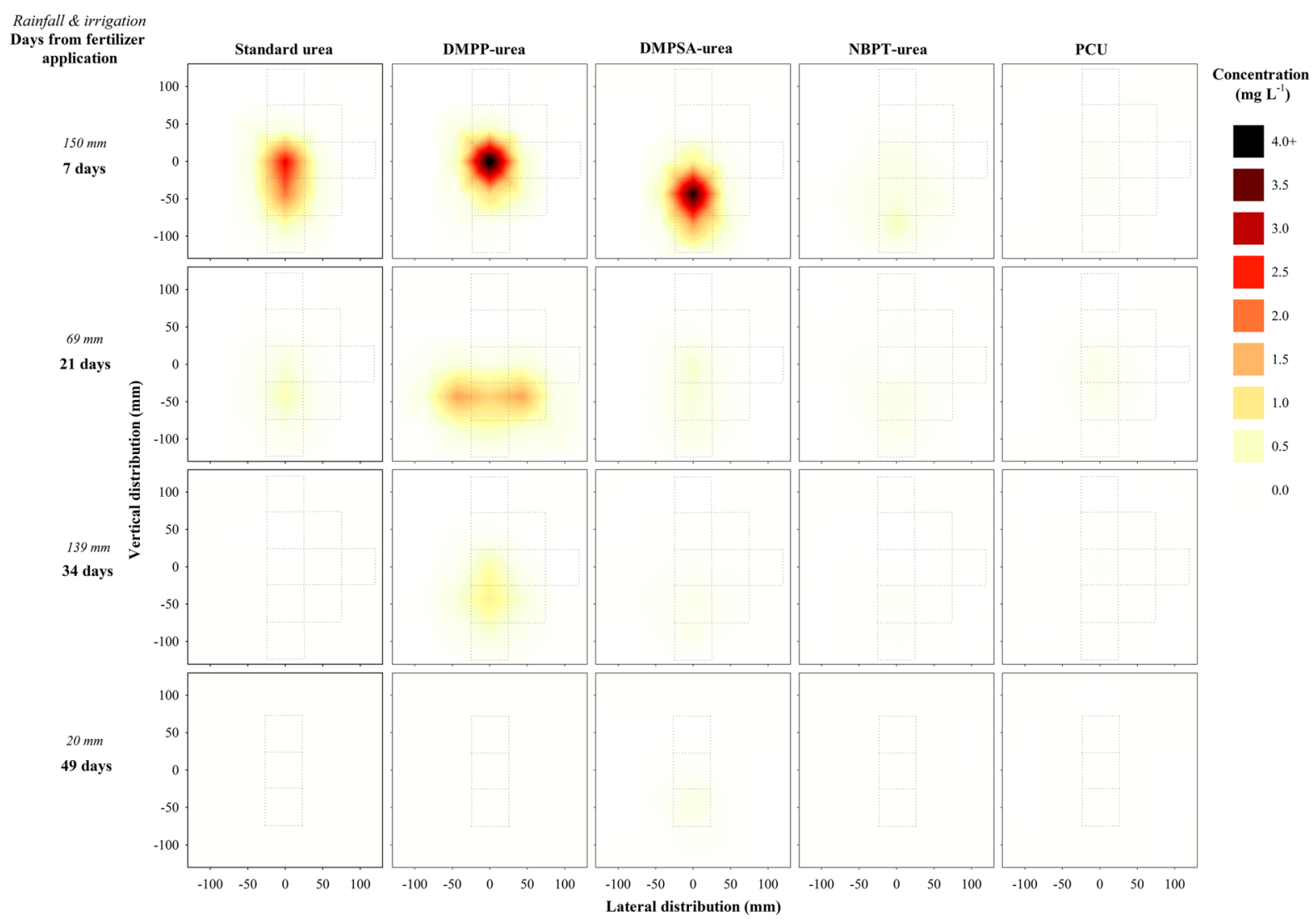

Fig. 4 The distribution of calculated aqueous $\mathrm{NH}_{3}$ concentrations $\left(\mathrm{mg} \mathrm{L}^{-1}\right)$ over time in response to banded $\mathrm{N}$-fertilizer treatments. Concentrations of aqueous $\mathrm{NH}_{3}$ were always $<0.1 \mathrm{mg} \mathrm{L}^{-1}$ in unfertilized soil and for all treatments after 49 days

the lower depths in the profile may therefore have also been a result of $\mathrm{N}$ re-distribution as aqueous $\mathrm{NH}_{3}$ that was subsequently converted back to $\mathrm{NH}_{4}-\mathrm{N}$ in the less alkaline and lower $\mathrm{NH}_{4}-\mathrm{N}$ environment at depth. By $34 \mathrm{DAF}, \mathrm{NH}_{4}-\mathrm{N}$ concentrations outside the fertosphere and the zone below had moderated to $<60 \mathrm{mg}$ $\mathrm{N} \mathrm{kg} \mathrm{soil}{ }^{-1}$ (Fig. 2), with concentrations of $\mathrm{NH}_{4}-\mathrm{N}$ immediately below the band being the last to decline below $100 \mathrm{mg} \mathrm{N} \mathrm{kg} \mathrm{soil}^{-1}$.

The decrease in $\mathrm{NH}_{4}-\mathrm{N}$ concentration with time (Fig. 2) was consistent with nitrification processes, although the time required for nitrification of the applied fertilizer was much longer than expected. There was little evidence of nitrification by 7 DAF, with high concentrations of $\mathrm{NH}_{4}-\mathrm{N}$ (ca. 700-900 mg $\mathrm{N} \mathrm{kg} \mathrm{soil}{ }^{-1}$ ) in the fertosphere and immediately below (i.e., zones 6 and 8, Fig. S2). At this time, concentrations of $\mathrm{NO}_{2}-\mathrm{N}$ and $\mathrm{NO}_{3}-\mathrm{N}$ represented $<2 \%$ of the total mineral $\mathrm{N}$ (Fig. 2), although these low concentrations may also be partly due to leaching or denitrification loss during the heavy rain that fell between fertilizer application and 7 DAF (Fig. 1). Nonetheless, the high concentrations of $\mathrm{NH}_{4}-$ $\mathrm{N}$ persisted in these regions during the drier period from 7 to $21 \mathrm{DAF}$ and $\mathrm{NO}_{2}-\mathrm{N}$ and $\mathrm{NO}_{3}-\mathrm{N}$ concentrations remained relatively low. In contrast, 40-60\% of the measured mineral $\mathrm{N}$ in zones outside of the fertosphere and soil immediately below (zones 6 and 8) was present as $\mathrm{NO}_{3}-\mathrm{N}$ by 21 DAF (Fig. 2). This indicates a strong and persisting inhibitory effect on nitrifying activity within the fertosphere and up to $75 \mathrm{~mm}$ below for up to $21 \mathrm{DAF}$.

Three key chemical changes associated with urea hydrolysis are known to contribute to nitrification inhibition, including (i) a shift to a more alkaline $\mathrm{pH}$; (ii) an increase in local salinity; and (iii) elevated aqueous $\mathrm{NH}_{3}$ concentrations. While the functional $\mathrm{pH}$ limits of nitrifiers vary considerably across a range of soil types (Guo et al. 2017; Nicol et al. 2008; Silva et al. 2012; Ying et al. 2017) increases of nearly $1 \mathrm{pH}$ 
unit were observed in the fertosphere and immediately below the urea band (Fig. 3) in this study. This created a nearly 10 -fold change in the $\mathrm{H}^{+}$concentration relative to what the indigenous nitrifying population were adapted to (Nicol et al. 2008; Ying et al. 2017) and is likely to have disrupted nitrifying activity. Previous studies have also identified substantial increases in EC as inhibitory to nitrification due to the osmotic effect that high salt concentrations have on nitrifying organisms (Claros et al. 2010; McClung and Frankenberger 1985, 1987; McCormick and Wolf 1980). However, in the urea-treated soil in this field experiment, the measured EC was best correlated (data not shown) with fluctuations in the concentration of $\mathrm{NO}_{2}-\mathrm{N}$ and $\mathrm{NO}_{3}-\mathrm{N}$, reflecting changes in the soluble salt concentration, rather than indicating zones of nitrification inhibition. The conditions of this field experiment (viz. large soil volume and movement of water through fertilizer bands) meant that inhibitory effects of raised EC on nitrification were unlikely to have occurred. However, it is noted that under dry field conditions the inhibitory effect of elevated EC on nitrification may have been greater, as soluble salts would not have moved out of the fertosphere and dispersed through a larger soil volume. Elevated aqueous $\mathrm{NH}_{3}$ may also have influenced the nitrification process, with known toxicities to Nitrosomonas at a minimum $\mathrm{NH}_{3}$ concentration of $10-150 \mathrm{mg} \mathrm{L}^{-1}$ and $0.1-4.0 \mathrm{mg} \mathrm{L}^{-1}$ for Nitrobacter (Anthonisen et al. 1976; Bae et al. 2001; Suthersan and Ganczarczyk 1986). According to these toxicity thresholds, only the second step of nitrification would have been inhibited in response to $\mathrm{NH}_{3}$ toxicity in this field study (Fig. 4). However, the aforementioned aqueous $\mathrm{NH}_{3}$ toxicity ranges were identified primarily from pure culture studies of specific bacteria (i.e., Nitrosomonas and Nitrobacter), and may not be representative of the $\mathrm{NH}_{3}$ sensitivity of a nitrifying community in soil. There are limited reports on $\mathrm{NH}_{3}$ sensitivity of nitrification in soils, although initial inhibitory effects on nitrification within the zone of fertilizer application have been observed in some field studies following the application of anhydrous $\mathrm{NH}_{3}$ fertilizer (Kyveryga et al. 2004; McIntosh and Frederick 1958). Given the strength of the inhibition observed at 7 DAF (i.e., very limited $\mathrm{NO}_{2}-\mathrm{N}$ and $\mathrm{NO}_{3}-\mathrm{N}$ production), it is suggested that substantial increases in both alkalinity and aqueous $\mathrm{NH}_{3}$ concentrations may have contributed to the inhibition of nitrification.
Although limited $\mathrm{NO}_{3}-\mathrm{N}$ was recovered at $34 \mathrm{DAF}$, a significant decline in $\mathrm{NH}_{4}-\mathrm{N}$ concentrations between 21 and 34 DAF (Fig. 2) was indicative of substantial nitrification over this time period. The general decline in $\mathrm{NO}_{3}-\mathrm{N}$ observed throughout the entire urea-treated soil profile between 21 and 34 DAF (Fig. 2) was likely the result of leaching into deeper soil layers or denitrification following ca. $140 \mathrm{~mm}$ of rainfall from 24 to 28 DAF (Fig. 1). By 49 DAF substantial concentrations of $\mathrm{NO}_{3}-\mathrm{N}$ had re-appeared in and below the fertosphere, indicating continuing net nitrification of the residual $\mathrm{NH}_{4}-\mathrm{N}$. At this time, $\mathrm{NO}_{3}-$ $\mathrm{N}$ represented $\mathrm{ca} .60 \%$ of the mineral $\mathrm{N}$ in each zone (i.e., zones 3, 6, 8, Fig. S2) of the $150 \times 150 \mathrm{~mm}$ soil column, with the balance of measured mineral $\mathrm{N}$ primarily found as $\mathrm{NH}_{4}-\mathrm{N}$.

Nitrification inhibitors prolong the inhibitory effects of urea bands

In comparison to standard urea, the inhibitory effects on nitrification were greater and persisted for longer in soil treated with high rates of DMPP-urea (Fig. 5) and DMPSA-urea (see Supplementary Material, Fig. S5). Concentrations of $\mathrm{NH}_{4}-\mathrm{N}$ were consistently higher and more widely distributed in profiles of the NI-urea treatments ( $c f$. Fig. 2), indicating reduced oxidisation and greater movement of $\mathrm{N}$ as aqueous $\mathrm{NH}_{3}$ (Fig. 3).

In the DMPP-urea treatment, substantially higher $\mathrm{NH}_{4}-\mathrm{N}$ concentrations up to 71 DAF (Fig. 5) provide evidence for an extension of inhibitory effects of up to $c a .50$ days longer than that observed for standard urea (ca. 21 days of inhibition observed in standard urea bands), with this persistence primarily observed within the fertosphere and immediately below. At 49 $\mathrm{DAF}$, concentrations of $\mathrm{NO}_{3}-\mathrm{N}$ had started to increase considerably in DMPP-urea treated soil, but were still less than $50 \%$ of those recorded for standard urea. This extended period of inhibition contrasts to other studies that utilized mixed application and/or did not include a urea-based fertilizer (Chen et al. 2010; Guardia et al. 2018a, b; Irigoyen et al. 2003), in which inhibitory effects of DMPP were seen for only 14-30 days. Janke (2020) hypothesized that as DMPP primarily remains within the fertosphere (characterized by high $\mathrm{pH}$, raised salinity, and elevated aqueous $\mathrm{NH}_{3}$ concentrations), a large proportion of microbial activity and associated inhibitor degradation may be prevented, effectively inhibiting nitrification whilst preserving 


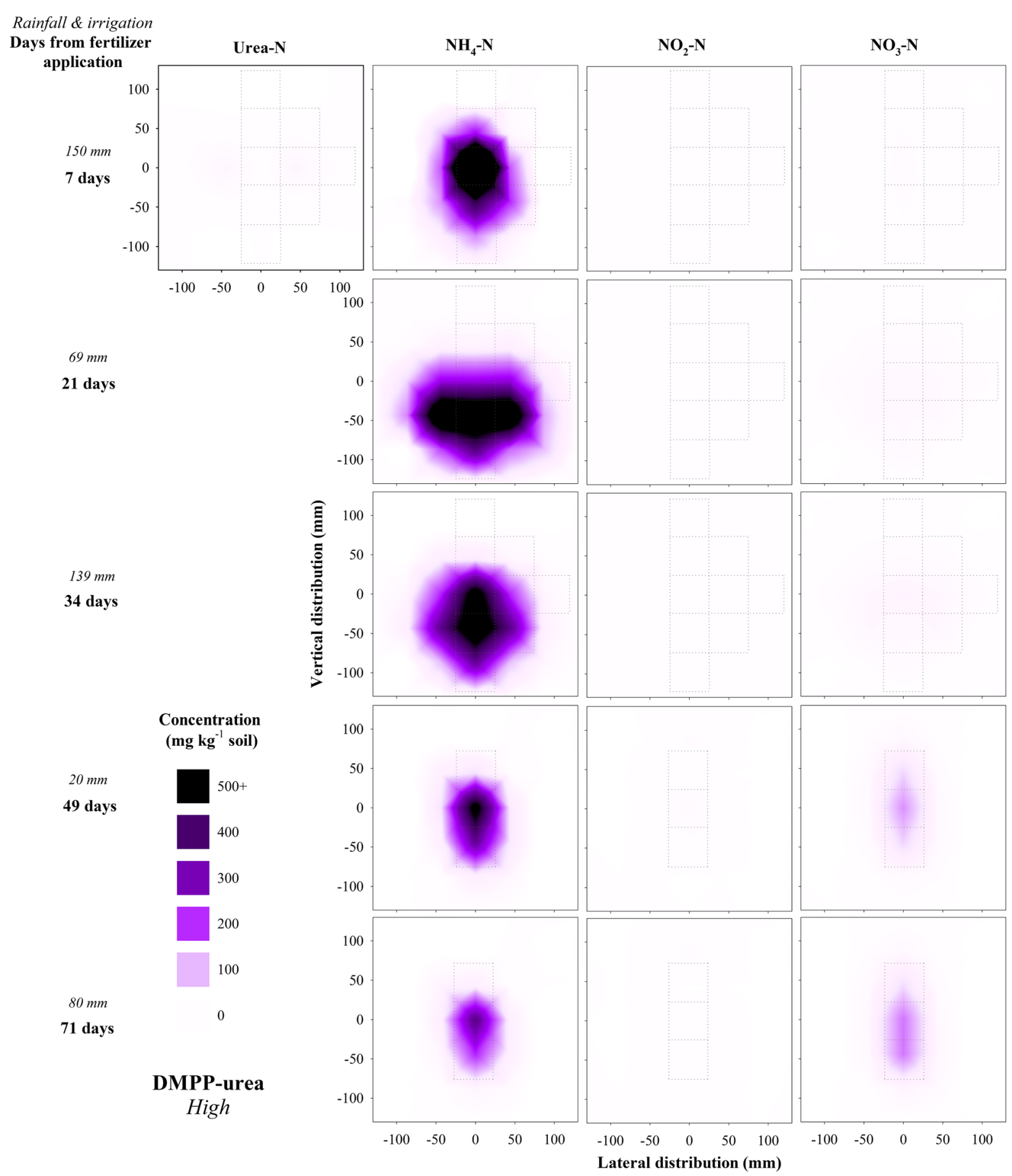

Fig. 5 Distribution of $\mathrm{N}$ species $\left(\mathrm{mg} \mathrm{N} \mathrm{kg}^{-1}\right.$ soil) over time in soil treated with the high in-band concentration $\left(27 \mathrm{~g} \mathrm{~N} \mathrm{~m}^{-1}\right)$ of banded DMPP-urea. No measurement of urea-N was taken after 7 days

the inhibitor. The prolonged nitrification inhibition at an equivalent in-band concentration (i.e., $27 \mathrm{~g} \mathrm{~N}$ $\mathrm{m}^{-1}$ ) of DMPP-urea in this field experiment, and also that of another field study under similar conditions (Scheer et al. 2016), supports this hypothesis. 
Over the trial period, DMPSA-urea did not demonstrate a greater or more prolonged inhibitory effect on nitrification compared to DMPP-urea (Figs. 5, S5), as had been claimed (Pacholski et al. 2016). While $\mathrm{NH}_{4}-$ $\mathrm{N}$ concentrations were similar to that of DMPP-urea throughout the trial period, concentrations of $\mathrm{NO}_{3}-\mathrm{N}$ were generally higher over the first $49 \mathrm{DAF}$, and significantly so at $21 \mathrm{DAF}$. It is postulated that the dependence on microbial degradation of succinic acid for DMPP release (Pacholski et al. 2016) may impair the initial effectiveness of DMPSA-urea in banded applications. The hostile conditions of a urea-based band may have a general inhibitory effect (Park et al. 2016; Rietz and Haynes 2003) on a range of microorganisms that are required for the 'release' of this inhibitor. Further investigation is required to determine whether this product is effective in banded applications.

The duration of NI-conferred inhibition is dependent on the rate of application

Increasing the rate of fertilizer application (i.e., inband concentrations) of urea and DMPP-urea progressively prolonged both net (Figs. 2, S6) and DMPPinduced (Figs. 5, S7) nitrification inhibition. Despite a three-fold increase of in-band fertilizer concentrations and consequent variations in $\mathrm{NH}_{4}-\mathrm{N}$ concentrations, $\mathrm{NO}_{3}-\mathrm{N}$ concentrations were similar at all application rates at $7 \mathrm{DAF}$. This was most likely indicative of inhibitory effects on nitrification due to the elevated $\mathrm{pH}$ and aqueous $\mathrm{NH}_{3}$ concentrations observed in and around the fertosphere (Figs. 3 and 4, S8, S9), but could also be partly due to loss of nitrification products in response to the rainfall which occurred between fertilizer application and 7 DAF (Fig. 1). Nonetheless, similar $\mathrm{NH}_{4}-\mathrm{N}$ concentrations between fertilizer treatments applied at the same rate (Fig. 6) suggest that at $7 \mathrm{DAF}$, chemical changes associated with urea hydrolysis (Figs. 3, 4 and 7, S8, S9) created conditions inhibitory to nitrification irrespective of NI addition or fertilizer application rate. However, by 21 DAF declining $\mathrm{NH}_{4}-\mathrm{N}$ concentrations in the low and medium urea treatments contrasted to those of DMPP-urea, indicating the initiation of DMPP-conferred inhibition in the lower application rates (Fig. 6). For the lowest fertilizer rate, the greatest effect from DMPP was seen at this time, with the average $\mathrm{NH}_{4}-\mathrm{N}$ concentration in the fertosphere and soil immediately below (i.e., zones 6 and 8) ca. 10-fold higher in the DMPP-urea treatment $c f$. standard urea. By 49 DAF, $\mathrm{NH}_{4}-\mathrm{N}$ concentrations were similar between fertilizer products at the low fertilizer application rate (Fig. 6), indicating that the inhibitor effects had fully dissipated by this time.

Soil treated with the medium and high rates of urea demonstrated sharp declines in $\mathrm{NH}_{4}-\mathrm{N}$ concentrations between 21 and 34 DAF, which was not observed in the DMPP-urea treatments at the same rates (Fig. 6), indicating an inhibitory effect of DMPP on nitrification. For the medium fertilizer treatment, this was the period of greatest benefit from DMPP-addition, with the concentration of $\mathrm{NH}_{4}-\mathrm{N}$ 14-fold higher $c f$. standard urea. While nitrification inhibition was still evident at 71 DAF in the medium fertilizer application rate, there was a much greater inhibitor-conferred effect at the highest fertilizer application rate at this time. This effect was manifest as much greater differences in $\mathrm{NH}_{4}-\mathrm{N}$ concentration between urea and DMPP-urea treatments (i.e., 20-fold higher for DMPP-urea). The trend of increasing nitrification inhibition with fertilizer application rate suggests an even longer inhibitory period was possible at the high in-band concentration than was observed over this 71-day experiment.

While net nitrification observed in urea bands is attributed to large and persistent changes in soil chemistry (Figs. 3, 4 and 7, S8, S9), increasing nitrification inhibition at higher in-band concentrations of DMPP-urea suggests that DMPP may also have a 'saturating' effect on soil microbes within the fertosphere. Increasing the rate of DMPP-urea to achieve higher in-band $\mathrm{N}$ concentrations also increased the in-band concentration of DMPP (6-17 $\mathrm{mg}$ DMPP $\mathrm{m}^{-1}$ band). Despite the ratio of DMPP:N remaining constant at all fertilizer application rates, a similar volume of soil (i.e., the fertosphere) received up to three-fold more inhibitor at the high in-band concentration compared to the lowest fertilizer application rate. In addition, the presence of DMPP with banded urea appeared to exacerbate conditions hostile to microbes (i.e., raised $\mathrm{pH}$ and aqueous $\mathrm{NH}_{3}$ ), with such conditions dissipating later in DMPP-urea bands applied at the same in-band concentrations as standard urea (Figs. 3, 4 and 7, S8, S9). This is likely an effect of DMPP-induced $\mathrm{NH}_{4}-\mathrm{N}$ preservation limiting nitrification-driven $\mathrm{pH}$ decreases 


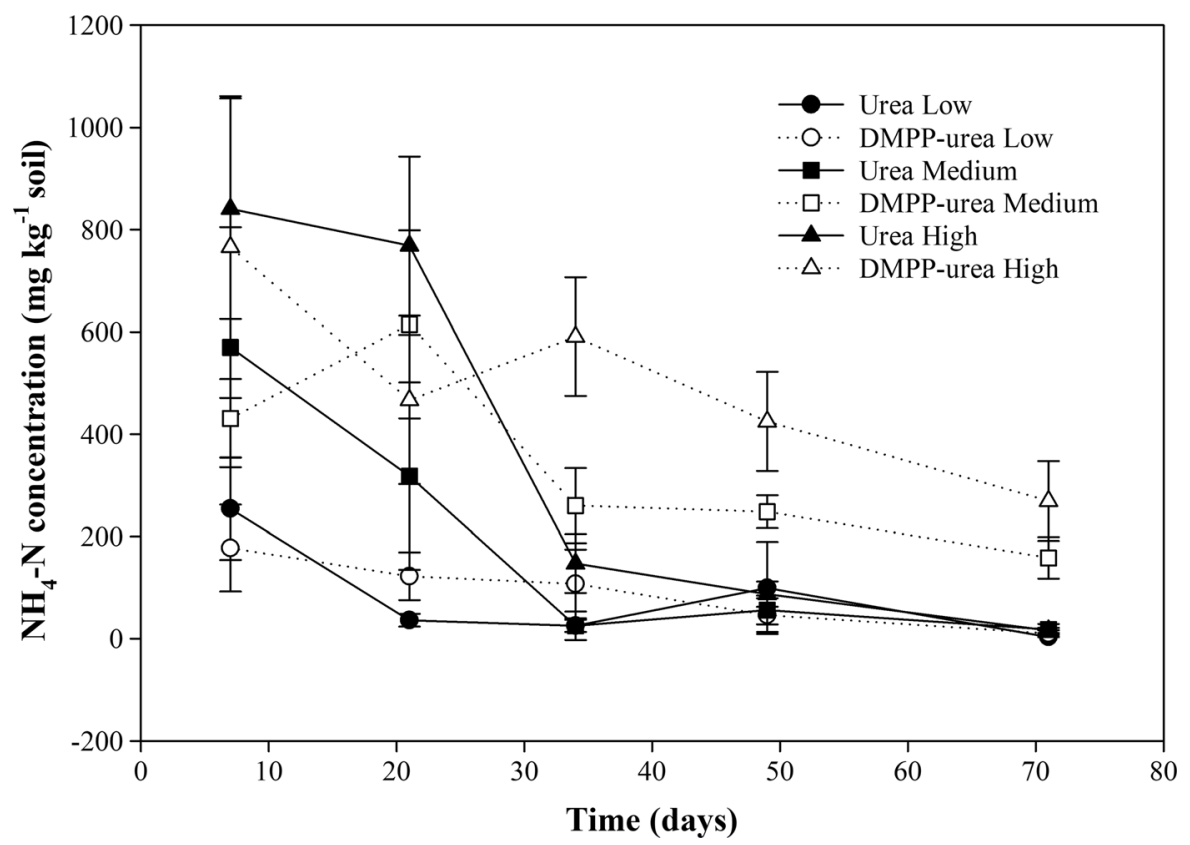

Fig. 6 The average $\mathrm{NH}_{4}-\mathrm{N}$ concentration $\left(\mathrm{mg} \mathrm{N} \mathrm{kg}^{-1}\right.$ soil) of the fertosphere and soil immediately below (zones 6 and 8 , Fig. S2) over time in urea and DMPP-urea treatments

and the maintenance of high aqueous $\mathrm{NH}_{3}$ concentrations.

NI fertilizers may allow $\mathrm{N}$ rate reductions

Similar indicators of plant-available $\mathrm{N}$ (i.e., concentrations of $\mathrm{NO}_{3}-\mathrm{N}$ and total mineral $\mathrm{N}$ ) were observed in the soil profile from the medium in-band concentrations of DMPP-urea (Fig. S7B) and the high in-band concentrations of urea (Fig. 2) from ca. 34 DAF. This observation suggests that application rates of $\mathrm{N}$ may be able to be reduced when using DMPP-urea ( $c f$. standard urea) without adversely affecting $\mathrm{N}$ availability for crops. However, this may only apply to crops that do not require substantial $\mathrm{N}$ uptake immediately following fertilizer application, as $\mathrm{N}$ availability was considerably lower for the moderate DMPPurea rate over the initial $34 \mathrm{DAF}$. Further, phytotoxic conditions in and around the fertosphere (Figs. 3, 4 and 7) may restrict early access of crop roots to fertilizer-N (Court et al. 1964a, b; Passioura and Wetselaar 1972). This suggestion is circumstantially supported by some studies in crops with long growing seasons (i.e., sugarcane) which reported a similar quantum of crop $\mathrm{N}$ uptake from reduced $\mathrm{N}$ application rates of DMPP-urea compared to urea (Dowie et al.
2019; Wang et al. 2016). In contrast, studies of shortseason crops (i.e., cereals and grains), which have a much shorter and more intense periods of $\mathrm{N}$ demand, were unable to demonstrate additional crop $\mathrm{N}$ uptake from DMPP-urea ( $c f$. standard urea) despite reduced losses and increased mineral $\mathrm{N}$ availability in the soil profile (Lester et al. 2016; Schwenke and Haigh 2019).

Urease inhibitors have limited impact in banded applications

Banding NBPT-urea resulted in substantial inhibition of ureolytic activity up to 7 DAF within, laterally to $75 \mathrm{~mm}$, and below, the fertosphere (Fig. 8). Compared to standard urea, concentrations of urea-N were ca. 16-fold higher within the fertosphere of the NBPTurea treatment. Higher concentrations were also detected vertically to $125 \mathrm{~mm}$ and laterally to $75 \mathrm{~mm}$ from the band with the lateral and vertical displacement consistent with movement of urea-N from the fertosphere by mass flow (in response to the $150 \mathrm{~mm}$ of rain that had fallen after fertilizationFig. 1) and diffusion. However, by $34 \mathrm{DAF}$, the mineral $\mathrm{N}$ in soil profiles treated with NBPT-urea (Fig. 8) was similar to that of standard urea (Fig. 2). The lack of continued presence of elevated urea-N 


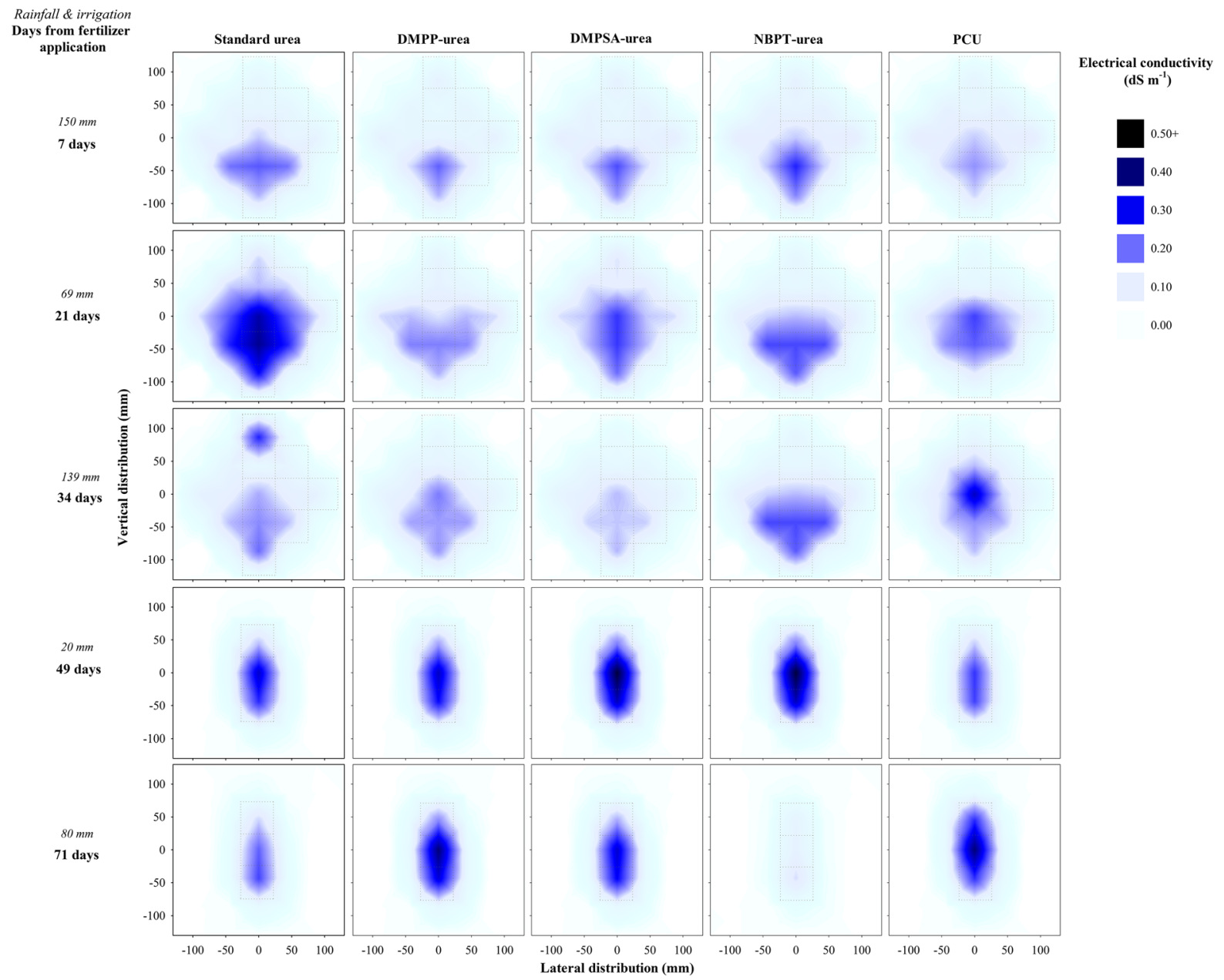

Fig. 7 Heat maps of changes in electrical conductivity $\left(\mathrm{dS} \mathrm{m}^{-1}\right)$ over time in response to banded N-fertilizer treatments

concentrations at 21 DAF $(<5 \%$ of the urea-N detected at 7 DAF) suggests that either the inhibitory effects of NBPT were short-lived, or that leaching prior to the 7 DAF sampling had caused a large amount of urea-N to move either below the measurement zone or simply away from the NBPT. While rapid leaching was unlikely in this low permeability soil, it is clear that at least some urea-N had moved into layers below the fertilizer band by $21 \mathrm{DAF}$. The relative immobility of banded NBPT in soils of high-clay and OM content has been recently identified by Janke (2020) and is likely a dominant factor in the rapid 'loss-of-function' observed in this and other studies (Watson et al. 1994; Adhikari et al. 2019). Soluble urea-N may diffuse and/ or move with mass flow, creating an asynchrony of inhibitor and substrate location that reduces the effectiveness of NBPT. Even limited leaching, as likely occurred in this study, may distribute urea-N beyond the zone of NBPT influence, which was measured at ca. $10 \mathrm{~mm}$ (i.e., within the fertosphere) in diffusion studies (Janke 2020). The transient effectiveness of NBPT once applied to soil is well known, and a range of soil factors may contribute to this. Rapid degradation has been found to occur under acidic conditions (Engel et al. 2015) and elevated temperatures (Watson et al. 2008), and loss-of-function is reported at high soil moisture content (Cantarella et al. 2018; Sanz-Cobena et al. 2016). While soil acidity is unlikely to have contributed to the degradation of NBPT in this trial (Table 1; Fig. 3), elevation of both soil moisture and temperature at various times between 7 and 21 DAF (Fig. 1) may have had an effect on NBPT performance. Anaerobic soil conditions can prevent the oxidisation of NBPT to 


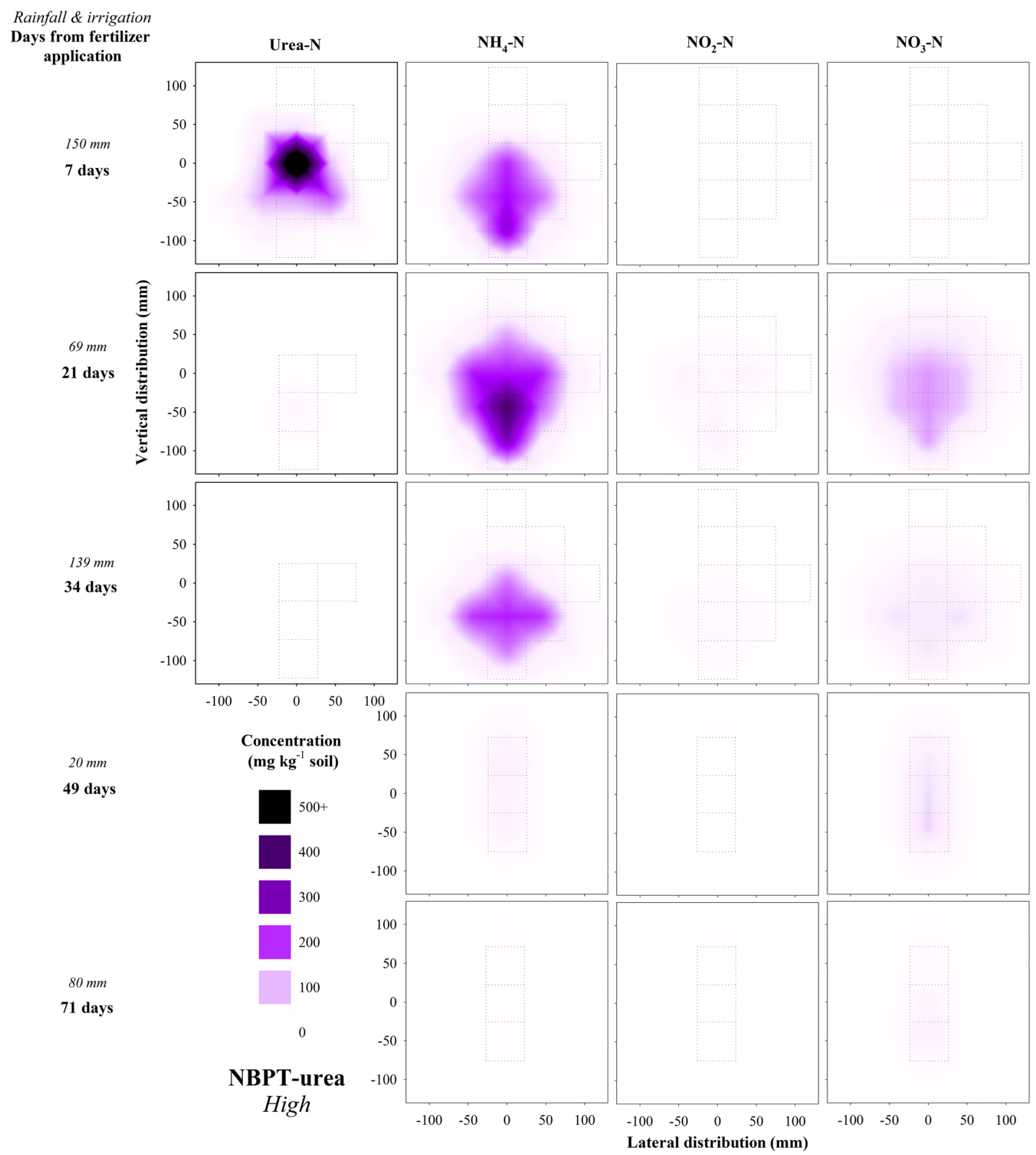

Fig. 8 Distribution of $\mathrm{N}$ species ( $\mathrm{mg} \mathrm{N} \mathrm{kg}^{-1}$ soil) over time in soil treated with the high in-band concentration $\left(27 \mathrm{~g} \mathrm{~N} \mathrm{~m}^{-1}\right)$ of banded NBPT-urea. No measurement of urea-N was taken after 34 days

NBPTO, which is the molecule that is 'active' in inhibiting urease (Manunza et al. 1999). However, despite the heavy early rainfall (Fig. 1) and resulting high soil moisture content, the presence of considerably higher concentrations of urea-N in the profile treated with NBPT-urea ( $c f$. urea) at 7 DAF indicates that conditions were not sufficiently oxygen-limited to prevent the formation of NBPTO. An increase in soil temperatures to $\mathrm{ca} .28^{\circ} \mathrm{C}$ may have increased the rate of chemical degradation of NBPT (Watson et al. 2008) 
between 7 and $21 \mathrm{DAF}$, contributing to the gradual decrease in urea-N over this period. Increased soil temperatures may also enhance enzymatic activity which can outpace the conversion of NBPT to NBPTO (Carmona et al. 1990), further contributing to reduced inhibitor efficacy.

The transient effectiveness of this inhibitor in concentrated bands is consistent with other studies that utilized broadcast and/or incorporated UI (Cantarella et al. 2018; Sanz-Cobena et al. 2012; Singh et al. 2013) in that inhibitory effects were only observed for $c a .21$ days. Banding therefore does not appear to influence the efficacy of the UI when compared to broadcast and/or incorporated applications. However, the potential for banded UI to reduce $\mathrm{N}$ losses ( $c f$. standard urea) and improve crop recovery of fertilizer- $\mathrm{N}$ appears limited. The mechanism of regulating urea hydrolysis is primarily targeting reducing gaseous $\mathrm{NH}_{3}$ losses, which is not a major $\mathrm{N}$ loss pathway in sub-surface bands (Rochette et al. 2013a, b). Further, significantly lower increases in $\mathrm{pH}$ (Fig. 3) and formation of aqueous $\mathrm{NH}_{3}$ (Fig. 4) in and around NBPT-urea bands (cf. standard urea) enabled formation of similar concentrations of $\mathrm{NO}_{3}-\mathrm{N}$ to that of standard urea, despite lower concentrations of $\mathrm{NH}_{4}-\mathrm{N}$ (Figs. 2 and 8). This, combined with the preservation of $\mathrm{N}$ in the moderately soluble form of urea, may result in increased leaching as urea-N or $\mathrm{NO}_{3}-\mathrm{N}$ (Dawar et al. 2011; Ma et al. 1995) and/or denitrification $\left(\mathrm{NO}_{3}-\mathrm{N}\right)$ loss of $\mathrm{N}$ in conditions where soil moisture content is high.

Controlled-release urea delivers a low basal supply of rapidly nitrified $\mathrm{N}$

In contrast to the soluble N-fertilizers, banded PCU resulted in a persistent supply of urea-N to the soil solution until at least $34 \mathrm{DAF}$, with concentrations of urea- $\mathrm{N}$ primarily located in the fertosphere and directly below (Fig. 9). Over the measurement period to $34 \mathrm{DAF}$, peak urea- $\mathrm{N}$ recovery in soil solution occurred at 21 DAF in the same zones, and while urea$\mathrm{N}$ concentrations in soil had decreased significantly by 34 DAF, this decrease may simply have been a response to the intense rainfall that occurred from 25 to $28 \mathrm{DAF}$ (Fig. 1). Indeed, the persistently high $\mathrm{NH}_{4}-$ $\mathrm{N}$ concentrations (Fig. 9) suggest release of urea-N to soil solution continued for much longer. However, the slow release of $\mathrm{N}$ from PCU granules resulted in the formation of $\mathrm{N}$ concentration gradients in soil solution that were considerably lower than that of standard urea, with $\mathrm{N}$ distribution reduced by $c a .50 \mathrm{~mm}$ in soil profiles ( $c f$. standard urea, Figs. 2 and 9). In dry conditions, the dispersal of $\mathrm{N}$ from the fertilizer band would likely be much lower, resulting in a smaller volume of soil $\mathrm{N}$ enrichment in and around the fertilizer band. Consequently, effective crop $\mathrm{N}$ uptake from PCU-N bands would rely on close seed placement to the fertilizer band and/or the development of a prolific root system in order to access the considerably reduced $\mathrm{N}$-rich zone of soil.

In response to lower ureolytic rates (i.e., less urea available for hydrolysis at a given time), the changes in soil chemistry (Figs. 3 and 7) and aqueous $\mathrm{NH}_{3}$ concentration (Fig. 4) were of lesser magnitude in and around the PCU fertosphere, resulting in rapid nitrification (Fig. 9). While $\mathrm{NO}_{3}-\mathrm{N}$ concentrations were comparatively lower than for other $\mathrm{N}$-fertilizer treatments up to $21 \mathrm{DAF}$, the average ratio of $\mathrm{NO}_{3}-\mathrm{N}$ to $\mathrm{NH}_{4}-\mathrm{N}$ throughout the profile of soil treated with PCU (ca. $46 \%$, Fig. 9) was similar to that of standard urea (ca. 45\%, Fig. 2). Further, from 49 DAF, concentrations of $\mathrm{NO}_{3}-\mathrm{N}$ were higher in soil profiles of PCUtreated soil compared to other $\mathrm{N}$-fertilizer treatments. This indicates a potentially longer window of risk for $\mathrm{N}$ loss via leaching or denitrification with this EEF if the later-released $\mathrm{N}$ is not captured by an actively growing crop. The frequent assessment of PCU performance at set time points, which typically do not extend to a timeframe whereby $\mathrm{N}$ release from PCU products is considered 'complete', potentially underestimates the risks of $\mathrm{N}$ losses from these products. Further, studies which investigate the efficacy of PCU products by assessing performance based on gaseous emission and crop yield indicators ( $\mathrm{Li}$ et al. 2015; Rahman et al. 2018) may overlook N lost via leaching, which has been reported in several studies (LeMonte et al. 2016; Nelson et al. 2009) (Fig. 9).

\section{Conclusions}

The inhibition of nitrification in response to rapid hydrolysis of concentrated urea bands indicates that the benefit of NIs will not be realised until the conditions in and around the band became more favourable for nitrification. Increasing the rate of DMPP-urea application increases the extent and 


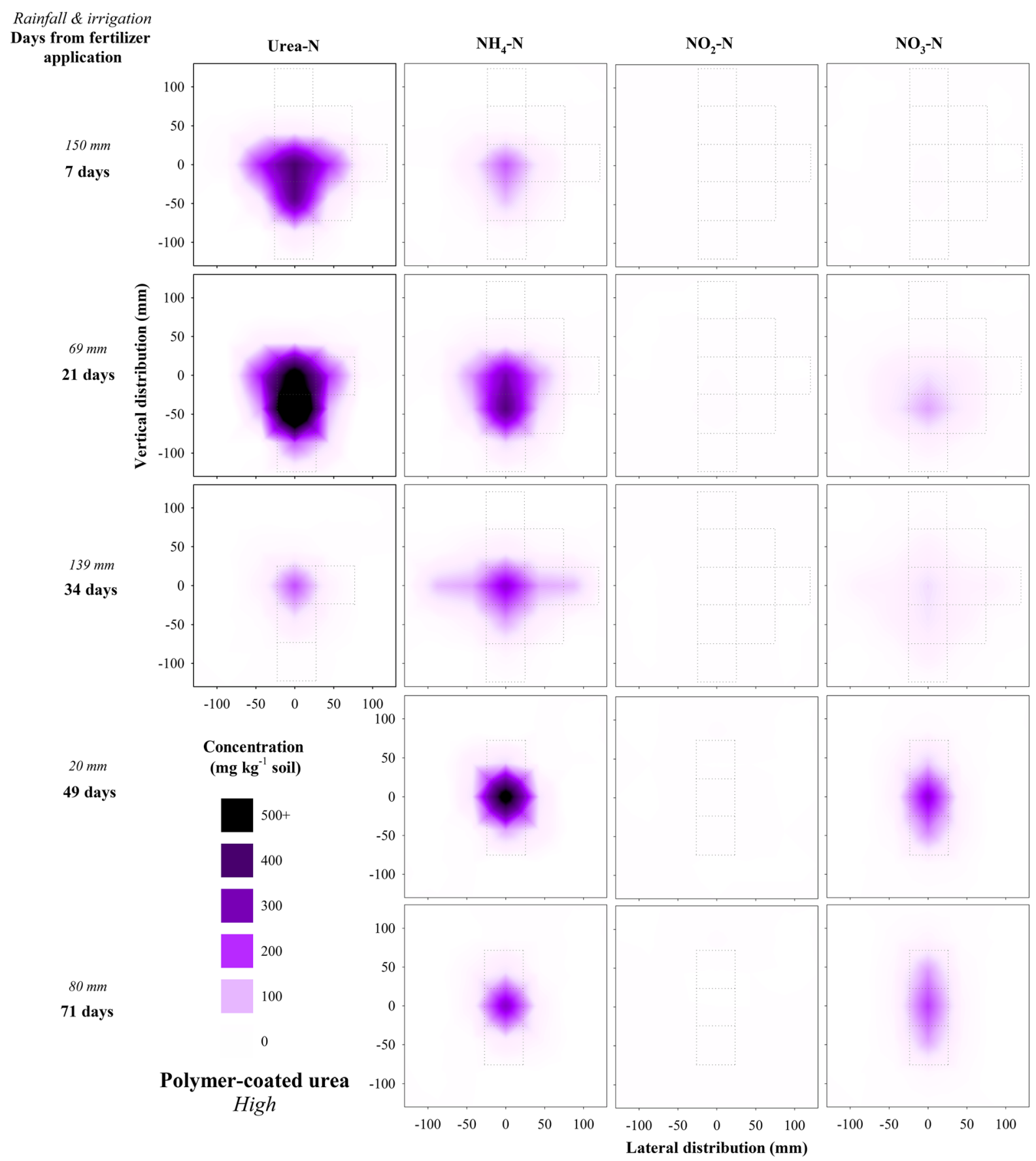

Fig. 9 Distribution of $\mathrm{N}$ species ( $\mathrm{mg} \mathrm{N} \mathrm{kg}^{-1}$ soil) over time in soil treated with the high in-band concentration $\left(27 \mathrm{~g} \mathrm{~N} \mathrm{~m}^{-1}\right)$ of banded polymer-coated urea. No measurement of urea-N was taken after 34 days

duration of inhibitory effects, which has important implications for synchronising the availability of $\mathrm{N}$ from concentrated DMPP-urea bands with crop requirements.
Whilst some urea-N was preserved for $c a .7$ days, banding UIs did not appear to offer any significant NUE benefits. Further, the preservation of $\mathrm{N}$ as urea-N and the relatively rapid nitrification of available $\mathrm{NH}_{4}-$ 
$\mathrm{N}$ may increase the risk of leaching and denitrification losses in environments and soil types which facilitate these loss pathways.

Compared to soluble forms of urea, PCU delivered lower daily $\mathrm{NH}_{4}-\mathrm{N}$ and $\mathrm{NO}_{3}-\mathrm{N}$ concentrations which may protect $\mathrm{N}$ from leaching and denitrification losses in isolated instances of high rainfall/irrigation soon after fertilizer application. However, distribution of $\mathrm{N}$ from the band is also reduced, resulting in a smaller $\mathrm{N}$-enriched zone of soil. Banded PCU appears best suited for delivering a low, basal supply of $\mathrm{N}$ to plants that have root zones in close proximity to the fertosphere.

This study provides a comprehensive understanding of the supply, availability and distribution of $\mathrm{N}$ from a range of EEF technologies when applied in concentrated bands. This knowledge may be incorporated into agronomic advice for the effective utilization of banded EEFs, with the aim of improving NUE in agricultural systems.

Acknowledgements This research was supported by the National Environmental Sciences Program (Tropical Water Quality Hub) project 2.1.8 'Improved Water Quality Outcomes from On-Farm Nitrogen Management'. Scholarship support from the Australian Government Research Training Program (RTP), Howard Memorial Trust, and Sugar Research Australia is gratefully acknowledged.

Open Access This article is licensed under a Creative Commons Attribution 4.0 International License, which permits use, sharing, adaptation, distribution and reproduction in any medium or format, as long as you give appropriate credit to the original author(s) and the source, provide a link to the Creative Commons licence, and indicate if changes were made. The images or other third party material in this article are included in the article's Creative Commons licence, unless indicated otherwise in a credit line to the material. If material is not included in the article's Creative Commons licence and your intended use is not permitted by statutory regulation or exceeds the permitted use, you will need to obtain permission directly from the copyright holder. To view a copy of this licence, visit http://creativecommons.org/licenses/by/4.0/.

\section{References}

Adhikari KP, Saggar S, Hanly JA, Guinto DF (2019) Comparing the effectiveness and longevity of the urease inhibitor $\mathrm{N}$-(2-nitrophenyl) phosphoric triamide (2-NPT) with N-(nbutyl) thiophosphoric triamide (nBTPT) in reducing ammonia emissions from cattle urine applied to dairygrazed pasture soils. Soil Res 57:719-728
Alonso-Ayuso M, Grabriel J, Quemada M (2016) Nitrogen use efficiency and residual effect of fertilizers with nitrification inhibitors. Eur J Agron 80:1-8

Anthonisen A, Loehr R, Prakasam T, Srinath E (1976) Inhibition of nitrification by ammonia and nitrous Acid. J Water Pollut Con F 48:835-852

Antil R, Gangwar M, Kumar V (2009) Transformation and movement of urea in soil as influenced by water application rate, moisture management regime, and initial moisture content. Arid Soil Res Rehab 6:319-325

Archer D, Halvorson AD, Reule CA (2008) Economics of irrigated continuous corn under conventional-till and no-till in Northern Colorado. Agron J 100:1166-1172

Aslam M, Travis RL, Rains DW (2001) Inhibition of net nitrate uptake by ammonium in Pima and Acala cotton roots. Crop Sci 41:1130-1136

Bae W, Baek S, Chung J, Lee Y (2001) Optimal operation factors for nitrite accumulation in batch reactors. Biodegradation 12:359-366

Barker D, Sawyer J (2017) Evaluation of nitrogen fertilizer additives for enhanced efficiency in corn on Iowa soils. Crop Forage Turfgrass Manag 3:1-6

Bathgate A, Pannell DJ (2002) Economics of deep-rooted perennials in western Australia. Agric Water Manag 53:117-132

Bell M, Briggs J, McKellar L et al (2014) A review of nitrogen use efficiency in sugarcane. Sugar Research Australia, Australia

Best E (1976) An automated method for the determination of nitrate nitrogen in soil extracts. Queensland J Agric Anim Sci 33:161-166

Bezdicek D, McaGregor J, Martin W (1971) The influence of soil-fertilizer geometry on nitrification and nitrate accumulation. Soil Sci Soc Am Pro 25:997-1002

Bhat M, Murthy D, Saidutta M (2011) Urea hydrolysis in saturated loam soil. J Agric Biol Sci 6:60-63

Bloom AJ (2015) The increasing importance of distringuishing among plant nitrogen sources. Curr Opin Plant Biol 25:10-16

Boutilier R, Shelton G (1980) The statistical treatment of hydrogen ion concentration and pH. J Exp Biol 84:335-339

Bremner J (1965) Inorganic forms of nitrogen. In: Black C (ed) Methods of Soil Analysis, Part 2. Chemical and Microbiological Properties. American Society of Agronomy Inc. Madison, Wisconsin, pp 1179-1237

Cantarella H, Otto R, Soares JR, Silva AG (2018) Agronomic efficiency of NBPT as a urease inhibitor: a review. J Adv Res 13:19-27

Carmo DL, Silva CA, Lima JM, Pinheiro GL (2016) Electrical conductivity and chemical composition of soil solution: comparison of solution sampler in Tropical soils. Rev Bras Cienc Solo 40

Carmona G, Christianson C, Byrnes B (1990) Temperature and low concentration effects of the urease inihibitor $\mathrm{N}-(\mathrm{n}$ butyl)thiophosphoric triamide (nBTPT) on ammonia volatilization from urea. Soil Biol Biochem 22:933-937

Chen D, Suter H, Islam A, Edis R (2010) Influence of nitrification inhibitors on nitrification and nitrous oxide $\left(\mathrm{N}_{2} \mathrm{O}\right)$ emission from a clay loam soil fertilized with urea. Soil Biol Biochem 42:660-664 
Christianson C, Baethgen W, Carmona G, Howard R (1993) Microsite reactions of urea-nBPT fertilizer on the soil surface. Soil Biol Biochem 25:1107-1117

Claros J, Jimenez E, Borras L, Aguado D, Seco A, Ferrer J, Serralta J (2010) Short-term effect of ammonia concentration and salinity on activity of ammonia oxidizing bacteria. Water Sci Technol 61:3008-3016

Court MN, Stephen RC, Waid JS (1964a) Toxicity as a cause of the inefficiency of urea as a fertilizer. II. Experimental. J Soil Sci 15:49-65

Court MN, Stephen RC, Waid JS (1964b) Toxicity as a cause of the inefficiency of urea as a fertilizers. I Review. J Soil Sci 15:42-48

Dawar K, Zaman M, Rowarth JS, Blennerhassett J, Turnbull MH (2011) Urea hydrolysis and lateral and vertical movement in the soil: effects of urease inhibitor and irrigation. Biol Fert Soil 47:139-146

Deane-Drummond CE, Glass ADM (1983) Short term studies of nitrate uptake into barley plants using ion-specific electrodes and ${ }^{36} \mathrm{ClO}_{3}^{-}$II. Regulation of $\mathrm{NO}_{3}{ }^{-}$efflux by $\mathrm{NH}_{4}{ }^{+}$. Plant Physiol 73:105-110

Dowie J, Thompson M, Anderson A (2019) A three-year assessment of controlled-release and nitrification-inhibiting fertilisers in the Burdekin. P Aus Soc Sugar Cane Technol 41:547-557

Emerson K, Russo R, Lund R, Thurston R (1975) Aqueous ammonia equilibrium calculations: Effect of $\mathrm{pH}$ and temperature. J fish Res Board Can 32:2379-2383

Engel R, Towey B, Gravens E (2015) Degradation of the urease inhibitor NBPT as affected by soil pH. Soil Sci Soc Am J 76:1674-1683

Erickson R (1985) An evaluation of mathematical models for the effects of $\mathrm{pH}$ and temperature on ammonia toxicity to aquatic organisms. Water Res 19:1047-1058

Fageria VD (2001) Nutrient interactions in crop plants. J Plant Nutr 24:1269-1290

Galloway J, Aber J, Erisman J, Seitzinger S, Howarth R, Cowling E, Cosby B (2003) The nitrogen cascade. Bioscience 53:341-356

George J (2014) Nitrate and ammonium interactions in maize. Dissertation. The University of Adelaide

Gerla PJ (2013) Can $\mathrm{pH}$ and electrical conductivity monitoring reveal spatial and temporal patterns in wetland geochemical processes? Hydrol Earth Syst Sci Discuss 10:699-728

Guardia G, Marsden KA, Vellejo A, Jones DL, Chadwick DR (2018a) Determining the influence of environment and edaphic factors on the fate of the nitrification inhibitors DCD and DMPP in soil. Sci Total Environ 624:1202-1212

Guardia G, Vallejo A, Gardenas L, Dixon E, Garcia-Marco S (2018b) Fate of ${ }^{15} \mathrm{~N}$-labelled ammonium nitrate with or without the new nitrification inhibitor DMPSA in an irrigated maize crop. Soil Biol Biochem 116:193-202

Guo J, Ling N, Chen H et al (2017) Distinct drivers of activity, abundance, diversity and composition of ammonia-oxidizers: evidence from a long-term field experiment. Soil Biol Biochem 115:403-414

Hatfield J, Follett RF (2008) Nitrogen in the environment: sources, problems, and management, 2nd edn. Elsevier Science, Burlington

Hauck R, Stephenson H (1965) Nitrogen sources, nitrification of nitrogen fertilizers. Effect of nitrogen source, size and $\mathrm{pH}$ of granule, and concentration. J Agric Food Chem 13:486-492

Hoopen F, Cuin TA, Pedas P, Hegelund JN, Shabala S, Schjoerring JK, Jahn TP (2010) Competition between uptake of ammonium and potassium in barley and Arabidopsis roots: molecular mechanisms and physiological consequences. J Exp Bot 61:2303-2315

Impact Fertilizers (2019) Agromaster. Impact Fertilizers. http:// www.impactfertilisers.com.au/products/specialtyfertilisers/agromaster/. Accessed 9th Janurary 2019

Irigoyen I, Muro J, Azpilikueta M, Aparicio-Tejo P, Lamsfus C (2003) Ammonium oxidation kinetics in the presence of nitrification inhibitors DCD and DMPP at various temperatures. Aus J Soil Res 41:1177-1183

Isbell R (2016) The Australian soil classification, 2nd. CSIRO Publishing,Melbourne, VIC

Janke CK, Fujinuma R, Moody P, Bell MJ (2019) Biochemical effects of banding limit the benefits of nitrification inhibition and controlled release technology in the fertosphere of high N-input systems. Soil Res 57:28-40

Janke CK (2020) The impact of banding urea and enhanced efficiency fertilizers on nitrogen transformations and the implications for nitrogen use efficiency in high-risk environments, Dissertation, University of Queensland

Kawakami EM, Oosterhuis DM, Snider JL, Mozaffari M (2012) Physiological and yield responses of field-grown cotton to application of urea with the urease inhibitor NBPT and the nitrification inhibitor DCD. Eur J Agron 43:147-154

Kyveryga PM, Blackmer AM, Ellsworth JW, Isla R (2004) Soil $\mathrm{pH}$ effect on nitrification of fall-applied anhydrous ammonia. Soil Sci Soc Am J 68:545-551

Lee R, Purves J, Ratcliffe R, Saker L (1992) Nitrogen assimilation and the control of ammonium and nitrate absorption by maize roots. J Exp Bot 43:1385-1396

Lemaire G, Charrier X, Hebert Y (1996) Nitrogen uptake capacities of maize and sorghum crops in different nitrogen and water supply conditions. Agronomie 16:231-246

LeMonte JJ, Jolley VD, Summerhays JS, Terry RE, Hopkins BG (2016) Polymer coated urea in turfgrass maintains vigor and mitigates nitrogen's environmental impacts. PLoS One

Lester DW, Bell MJ, Bell KL, Migliorati MDA, Scheer C, Rowlings D, Grace PR (2016) Agronomic responses of grain sorghum to DMPP-treated urea on contrasting soil types in north-eastern Australia. Soil Res 54:565-571

Li N, Ning T, Cui Z, Tian S, Li Z, Lal R (2015) $\mathrm{N}_{2} \mathrm{O}$ emission and yield in maize field fertilized with polymer-coated urea under subsoiling or rotary tillage. Nutr Cycl Agroecosys 102:397-410

Ma L, Hongprayoon C, Lindau CW, Selim HM (1995) Transport of urea in flooded soil profiles as affected by water percolation rates and NBPT. Soil Sci 160:101-110

Manunza B, Deiana S, Pintore M, Gessa C (1999) The binding mechanis of urea, hydroxamic acid and N-(N-butyl)phosphoric triamide to the urease active site. A comparative molecular dynamics study. Soil Biol Biochem 31:789-796

McCarty G (1999) Modes of action of nitrification inhibitors. Biol Fertil Soils 29:1-9

McClung G, Frankenberger W (1985) Soil nitrogen transformations as affected by salinity. Soil Sci 139:405-411 
McClung G, Frankenberger W (1987) Nitrogen mineralization rates in saline vs. salt-amended soils. Plant Soil 104:13-21

McCormick R, Wolf D (1980) Effect of sodium chloride on $\mathrm{CO}_{2}$ evolution, ammonification, and nitrification in a Sassafras sandy loam. Soil Biol Biochem 12:153-157

McIntosh TH, Frederick LR (1958) Distribution and nitrification of anhydrous ammonia in a Nicollet Sandy Clay Loam. Soil Sci Soc Am Pro 22:402-405

MicroSolv (2010) Analysis of urea: fast, reproducible HLPC method. In: HPLC application note (APP-A-111). http:// mtc-usa.host4kb.com/getAttach/1183/AA-00663/

No+111+Analysis+of+Urea.pdf. Accessed 16th Janurary 2018

Muller B, Touraine B (1992) Inhibition of $\mathrm{NO}_{3}{ }^{-}$uptake by various phloem-translocated amino acids in soybean seedlings. J Exp Bot 43:617-623

Nash PR, Nelson KA, Motavalli PP (2013) Corn yield response to polymer and non-coated urea placement and timings. Int J Plant Prod 7:373-392

Nelson KA, Paniagua SM, Motavalli PP (2009) Effect of polymer coated urea, irrigation, and drainage on nitrogen utilization and yield of corn in a claypan soil. Agronomy Journal 101

Nicol GW, Leininger S, Schleper C, Prosser JI (2008) The influence of soil $\mathrm{pH}$ on the diversity, abundance and transcriptional activity of ammoni oxidizing archaea and bacteria. Environ Microbiol 10:2966-2978

Nye PH (1979) Diffusion of ions and uncharged solutes in soil and soil clays. Adv Agron 31:225-272

Pacholski A, Berger N, Bustamante I, Ruser R, Guardia G, Mannheim T (2016) Effects of the novel nitrification inhibitor DMPSA on yield, mineral $\mathrm{N}$ dynamics and $\mathrm{N}_{2} \mathrm{O}$ emissions. Proceedings of the International Nitrogen Conference, Melbourne

Park S, Cui F, Mo K, Kim M (2016) Mathematical models and bacterial communities for ammonia toxicity in mesophilic anaerobes not acclimated to high concentrations of ammonia. Water Sci Technol 74:935-942

Passioura J, Wetselaar R (1972) Consequences of banding nitrogen fertilizers in soil. II. Effects on the growth of wheat roots. Plant Soil 36:461-473

Pierret A, Maeght J, Clement C, Montoroi J, Hartmann C, Gonkhamdee S (2016) Understanding deep roots and their functions in ecosystems: an advocacy for more unconventional research. Annuals of Botany 118:621-635

Rahman NSA, Yunus R, Ishak C, Khan SH (2018) Laboratory evaluation on ammonia volatilization from coated urea fertilizers. Commun Soil Sci Plan 49:717-724

Rayar AJ, van Hai T (1977) Effect of ammonium on uptake of phosphorus, potassium, calcium and magnesium by intact soybean plants. Plant Soil 48:81-87

Rayment G, Lyons D (2010) Soil Chemical methods. Australasia, CSIRO Publishing, Collingwood

Rietz DN, Haynes RJ (2003) Effects of irrigation-induced salinity and sodicity on soil microbial activity. Soil Biol Biochem 35:845-854

Robinson N, Brackin R, Vinall K et al (2011) Nitrate paradigm does not hold up for sugarcane. PLoS One

Rochester IJ, Bange M (2016) Nitrogen fertiliser requirements of high-yielding irrigated transgenic cotton. Crop Pasture Sci 67:641-648
Rochette P, Angers DA, Chantigny MH, Gasser M, MacDonald JD, Pelster DE, Bertrand N (2013a) Ammonia volatilization and nitrogen retention: how deep to incorporate urea? J Environ Qual 42:1635-1642

Rochette P, Angers D, Chantigny M, Gasser M, MacDonald JD, Pelster DE, Bertrand N (2013b) $\mathrm{NH}_{3}$ volatilization, soil $\mathrm{NH}_{4}{ }^{+}$concentration and soil $\mathrm{pH}$ following subsurface banding of urea at increasing rates. Can J Soil Sci 93:261-268

Rowlings D, Scheer C, Liu S, Grace P (2016) Annual nitrogen dynamics and urea fertilizer recoveries from a dairy pasture using ${ }^{15} \mathrm{~N}$; effect of nitrification inhibitor DMPP and reduced application rates. Agr Ecosyst Environ 216:216-225

Sanchez CA, Swanson S, Porter PS (1990) Banding P to improve fertilizer use efficiency of lettuce. J Am Soc Hort Sci 115:581-584

Sandral G, Tavakkoli E, Harris F, Koetz E, Angus J (2017) Improving nitrogen fertilier use efficiency in wheat using mid-row banding. Proceedings of the 18th Australian Society of Agronomy Conference, Ballarat

Sanz-Cobena A, Sanchez-Martin L, Garcia-Torres L, Vallejo A (2012) Gaseous emission of $\mathrm{N}_{2} \mathrm{O}$ and $\mathrm{NO}$ and $\mathrm{NO}_{3}{ }^{-}$ leaching from urea applied with urease and nitrification inhibitors to a maize (Zea mays) crop. Agri Ecosyst Environ 149:64-73

Sanz-Cobena A, Abalos D, Meijide A, Sanchez-Martin L, Vallejo A (2016) Soil moisture determine the effectivenses of two urease inhibitors to decrease $\mathrm{N}_{2} \mathrm{O}$ emission. Mitig Adapt Stat Gl 21:1131-1144

Scheer C, Rowlings DW, Migliorati MDA, Lester DW, Bell MJ, Grace PR (2016) Effect of enhanced efficiency fertilisers on nitrouse oxide emission in a sub-tropical cereal cropping systems. Soil Res 54:544-551

Schwenke GD, Haigh BM (2019) Urea-induced nitrous oxide emissions under sub-tropical rain-fed sorghum and sunflower were nullified by DMPP, partially mitigated by polymer-coated urea, or enhanced by a blend of urea and polymer-coated urea. Soil Res 57:342-356

Searle P (1974) Automated colorimetric determination of ammonium ions in soil extracts with 'Technicon AutoAnalyzer II' equipment. New Zeal J Agr Res 18:183-187

Shaviv A (2001) Advances in controlled-release fertilizers. Adv Agron 71:1-49

Silva MCP, Poly F, Guilaumaud N, Elsas JD, Salles JF (2012) Fluctuations in ammonia oxidizing communitities across agricultural soils are driven by soil structure and $\mathrm{pH}$. Front Microbiol 3:1-22

Singh R, Nye P (1984) The effect of soil pH and high urea concentration on urease activity in soil. Eur J Soil Sci 35:519-527

Singh J, Kunhikrishnan A, Bolan NS, Saggar S (2013) Impact of urease inhibitor on ammonia and nitrous oxide emissions from temperate pasture soil cores receiving urea fertilizer and cattle urine. Sci Total Environ 465:56-63

Suthersan S, Ganczarczyk J (1986) Inhibition of nitrite oxidation during nitrification: some observations. Water Poll Res J Can 21:257-266

Taylor A, Bloom A (1998) Ammonium, nitrate, and proton fluxes along the maize root. Plant Cell Environ 21:1255-1263 
Thapa R, Chatterjee A, Awale R, McGranahan D, Daigh A (2016) Effect of enhanced efficiency fertilizers on nitrous oxide emission and crop yields: a meta-analysis. Soil Sci Soc Am J 80:1121-1134

Thorburn P, Biggs J, Webster A, Biggs I (2011) An imprvoed way to determine nitrogen fertiliser requirements of sugarcane crops to meet global environmental challenges. Plant Soil 339:51-67

Thorup-Kristensen K (2006) Effect of deep and shallow root systems on the dynamics of soil inorganic $\mathrm{N}$ during 3-year crop rotations. Plant Soil 288:233-248

Trenkel M (2010) Slow-and controlled-release and stabilized fertilizers: an option of enhancing nutrient use efficiency in agriculture. International Fertilizer Industry Association, Paris

Wang W, Park G, Reeves S, Zahmel M, Heenan M, Salter B (2016) Nitrous oxide emission and fertiliser nitrogen efficiency in a tropical sugarcane cropping system applied with different formulations of urea. Soil Res 54:572-584

Watson CJ, Miller H, Poland P, Kilpatrick DJ, Allen MDB, Garrett MK et al (1994) Soil properties and the ability of the urease inhibitor N-(n-butyl) thiophosphoric triadmide (nBTPT) to reduce ammonia volatilization from surfaceapplied urea. Soil Biol Biochem 26:1165-1171

Watson CJ, Akhonzada NA, Hamilton JTG, Matthews DI (2008) Rate and mode of application of the urease inhibitor $\mathrm{N}$-(n-butyl) thiophosphoric triamide on ammonia volatilization from surface-applied urea. Soil Use Manag 24:246-253

Wetselaar R, Passioura J, Singh B (1972) Consequences of banding nitrogen fertilizers in soil I. Effects on nitrification. Plant Soil 36:159-175

Ying J, Li X, Wang N, Lan Z, He J, Bai Y (2017) Contrasting effects of nitrogen forms and soil $\mathrm{pH}$ on ammonia ozidizing microorganisms and their responses to long-term nitrogen fertilization in a typical steppe ecosystem. Soil Biol Biochem 107:10-18

Publisher's Note Springer Nature remains neutral with regard to jurisdictional claims in published maps and institutional affiliations. 